KAPITÁNY ÁGNES - KAPITÁNY GÁBOR ${ }^{1}$

VÁLASZTÁSI KAMPÁNY ÉS TÁRSADALMI INTEGRÁCIÓ

Dol: 10.18030/socio.hu.2015.4.108

ABSZTRAKT

Tanulmányunkban a vizsgálandó probléma - a választási kampány integrativ/dezintegratív szerepe - bemutatása után röviden ismertetjük elemzésünk szempontjait, majd összefoglaljuk az 2014-es kampány vizuális anyagainak analízise alapján kirajzolódó összképet, sorra vesszük a választási kampányanyagok egyes integratív (és jelentős mértékben dezintegrativ) alkotóelemeit. Kitérünk a negativ kampány jelenségének értékelésére, felidézzük az ország politikai megosztottságának történelmi okairól megfogalmazott hipotézisünket, majd számba vesszük a kampány integratív tényezőit is. Végül áttekintjük az integráció különböző szintjeinek viszonyát, és az egyes szintek eltérő szempontjainak ütközéséből adódó problémaforrásokat is.

Kulcsszavak: értékek, integráció/dezintegráció, negatív kampány, szimbolizáció, választási kampányok

\title{
ELECTION CAMPAIGN AND SOCIAL INTEGRATION
}

\section{ABSTRACT}

The essay analyses the possible integrative role of political campaigns. It summarizes some typical phenomena of the Hungarian parliamentary electoral campaign of 2014. The authors draw up a hypothesis about the reasons for the diversification of the Hungarian political field today. They interpret the phenomenon (and graduation) of negative campaign. Finally, they collect some problems caused by the conflict of different points of view of different integration scales.

Keywords: integration, electoral campaign, negative campaigning, symbols, values 


\section{VÁLASZTÁSI KAMPÁNY ÉS TÁRSADALMI INTEGRÁCIÓ}

\section{A PROBLÉMA}

A kiélesedő választási kampány-küzdelmek idején valóságidegennek tűnhet az olyan felvetés, amely a választási kampányok integrációs szerepét állítja a középpontba. Pedig a politikai demokráciának éppen az az egyik lényegi eleme-- a homogenizációra törekvő diktatúrákkal és despotizmusokkal szemben--, hogy a társadalomban jelenlévő különböző érdekeket (illetve a különböző érdekű csoportokat) úgy integrálják, hogy nekik egyúttal politikai érdekképviseletet nyújtanak, s ezek szembesülése, plurális reprezentációja, az antik értelemben vett politeia maga teremti meg az integrációt. A demokráciákat éppen az ilyen, a politikai mezőbe becsatornázott érdekartikuláció és az érdekek ezek alapján végrehajtott összeegyeztetésének lehetősége legitimálja. Ez az integrációs hatás azonban nem automatikusan érvényesül, további feltételek függvénye, hogy létrejön-e. A demokráciáknak újra meg újra létre kell hozniuk önmagukat, s integratív hatásukról csak akkor beszélhetünk, ha a) a társadalmat alkotó csoportok túlnyomó részének megvan a hatékony érdekképviselete; b) a különböző, egymással versengő és ütköző érdekek képviselőinek vannak olyan közös értékeik, amelyek alapján közöttük közös nevezők, az érdekek összeegyeztetését (s ezen keresztül a képviselt csoportok integrációját) lehetővé tévő konszenzusok képezhetők. A nyugati demokráciákban, azok integratív korszakaiban magának a (politikai) demokráciának, a demokratikus politikai pluralizmusnak, és a hatalmi centrumok erre épített többszörös kontrolljának az eszménye volt mindig az a részérdekeket felülíró érték, ami ezt az integrációt biztosítja, (és a demokráciát tagadó erőket a margóra szorítva, a demokrácia érvényesülésének élményét megerősítve a társadalom túlnyomó többségére valóban integráló hatást gyakorol). Problematikussá és sérülékennyé válik azonban ez az integráló hatás akkor, ha

- $\quad$ a politikai érdekartikuláció jelentős érdekek képviseletére nem terjed ki, illetve ha a politikai demokrácia nem alapul társadalmi (és gazdasági) demokrácián;

- $\quad$ az egymással versengő politikai érdekképviseletek tartósan kétségbe vonják egymás legitimitását, s ezzel tulajdonképpen azt deklarálják, hogy közöttük nincsen (integratív) közös nevező.

Mivel a társadalomban az integrációs törekvések mindig több, egymást tartalmazó rendszeregységben érvényesülnek (az emberiségtől az EU-hoz hasonló szerveződéseken és a nemzetállamokon át az egyes kisebb területegységekig és szubkultúrákig), az integrációt (mindegyik szint integrációját) erősíti, ha az egyes szintek integrációs törekvései nem egymás ellenében érvényesülnek; ütközésük azonban az egyes szintek belső integrációját is gyengítheti, problematikussá teheti.

Mindezt figyelembe véve a 2014-es magyarországi országgyúlési választási kampány az integrációs hatóeszközök tekintetében legalábbis ellentmondásosnak nevezhető; a Magyarországon az első szabad választások óta végigkövethető folyamat pedig hullámzónak, és az utóbbi tizenkét évben egyértelműen romlónak tekinthető (bár, mint látni fogjuk, jelentős hatások működnek az integráció irányában is). 


\section{AZ ELEMZÉS NÉZŐPONTJA ÉS MÓDSZEREI}

A kampányt az alábbiakban elsősorban abból a szempontból elemezzük, hogy az abban résztvevő politikai aktorok milyen módon próbáltak hatást gyakorolni: nem az integrációs hatást mértük, hanem az integrációs/dezintegrációs hatást kiváltani képes kampányanyagokat elemeztük, tehát nem a társadalom reakcióit, hanem azt, ahogyan a politikai aktorok törekvései ezekben az anyagokban megjelentek.

Ezen belül is elsősorban az értékek szerepére fókuszálunk, vizsgálatunk tárgyát - a politikai cselekvés igen összetett eszközrendszerének nagy részének elemzésétől már csak szakmai kompetenciánk korlátai miatt is eltekintve - döntően a kampányokban használt értékek, szimbólumok és az ezeket megjelenítő vizuális, auditív és egyéb eszközök képezik.

Elemzéseink különben sem politikai szempontból közelítették meg ezeket a kampányeszközöket; célunk mindig ezek szimbolikus szerepének feltárása: szimbólumelemzés volt (amelynek során egyrészt a nyelvi szövegeken folytatott klasszikus tartalomelemzés technikáit, másrészt a képi tartalmak meghatározásának vizuális anyagok elemzésénél szokásos módszereit: a szimbolikus antropológia és a szemiotika elemzési eszközeit használtuk)².

\section{VÁLASZTÁSI KAMPÁNY (2014) ÉS INTEGRÁCIÓ}

\section{Az elemzés szempontjai}

25 évet felölelő longitudinális vizsgálatunk keretében, az MTA TK Szociológiai Intézetében a rendszerváltás utáni első szabad választás, 1990 óta minden választási évben elvégeztük a választási kampányok szimbolikus és értéküzeneteinek elemzését (Kapitány-Kapitány 1990, 1994, 1998, 2003, 2007, 2010). Kezdetben ez elsősorban a választási kampányfilmek elemzését jelentette. Mivel azonban a pártok által készített kampányfilmek terjedelme, mennyisége és kampánybeli jelentősége választásról-választásra csökkent ${ }^{3}$ ugyanakkor egyre újabb és újabb eszközök jelentek meg a kampányokban, az elemzést fokozatosan kiterjesztettük egyéb kampányeszközökre is. A televízió kezdetben szinte egyeduralkodó szerepe megszúnt; először a szórólapok, óriásplakátok használata vált általánossá, majd egyre nagyobb lett a súlya az elektronikus hírtovábbítás olyan eszközeinek is, mint az Internet és a mobiltelefon (honlapok, közösségi oldalak, képmegosztó oldalak, SMS, you tube stb.). Mindezek mellett elemeztük még a plakát-átfirkálásokat is.

Elemzéseinkben az említett kampányeszközöket az alábbi szempontokból vizsgáltuk:

- melyek a megjelenített explicit és implicit kulcsértékek;

- melyek a megfogalmazott célok, a jövőre vonatkozó változtatási elképzelések;

2 Az elemzés módszertanához lásd: Jakobson-Halle (1956), Osgood-Suci-Tannenbaum (1957), Firth (1973), Geertz (1973), Turner (1974), Douglas (1975), Leach (1976), Cohen (1985), Turner (1987), Geertz (1994), Gerbner (2000), Babbie (2003) 352-363, Randviir-Cobley (2009), Hess-Lüttich (2009), Kiss (2013), illetve Kapitány-Kapitány (1996), Kapitány-Kapitány (1998/b), Kapitány-Kapitány (2006), Kapitány-Kapitány (2008), Kapitány-Kapitány (2009), Kapitány-Kapitány (2012), Kapitány-Kapitány (2014), Kapitány-Kapitány (2015).

3 A pártok száma is lényegében folyamatosan csökkent. Emlékeztetőül felidézzük, hogy hány párt állított listát az egyes választásokon 1990: 46; 1994: 15; 1998: 12; 2002: 8; 2006: 10; 2010: 6; 2014: 18. (Az utóbbi adat kissé félrevezető: mint a leadott szavazatok is mutatják, ezen a választáson lényegében már csak 4 párt, illetve pártszövetség játszott tényleges szerepet, s legfeljebb további 3-4-nek - de maximálisan is legfeljebb 7-8 „kispártnak”- voltak valamilyen jelenlétet sejtető médiamegjelenései, elemezhető kampányanyagai). 
- $\quad$ milyen emberi igényekre próbálnak építeni;

- melyek a kiemelt szlogenek;

- $\quad$ van-e ellenségkép, s ha igen, milyen;

- $\quad$ hogyan jelenik meg a kampányanyagokban a múlt, a jelen, a jövő;

- $\quad$ hogyan jelenik meg a kampányanyagokban a bal-, illetve jobboldaliság;

- $\quad$ hogyan jelenik meg a kampányanyagokban a nemzet, Európa, a nagyvilág;

- hogyan jelenik meg a kampányanyagokban a vallás;

- melyek a megjelenítés szenzuális elemei;

- $\quad$ a megjelenített szereplők; ezen belül: a szereplők

neme

életkora (külön figyelemmel a gyerekek szerepeltetésére és szerepére)

beszédstílusa, viselkedése (ezen belül külön figyelemmel a humor jelenlétére)

a szereplő személyek által reprezentált társadalmi csoport (külön figyelemmel a kisebbségekre)

egyén és tömeg viszonya a megjelenítésben

- a helyszín, a környezet;

- $\quad$ az alkalmazott vizuális effektek (fények, színek, képi montázshatások, trükkök);

- zene, hanghatások;

- utalnak-e kampányanyagok korábbi választásokra, (van-e valamiféle „építkezés”) s ha igen, miképpen;

- milyen a kampányanyagok alaphangulata (optimista/pesszimista) és irányultsága (pozitív/negatív);

- vannak- e „bakik”, akaratlan hatások, amelyek ellene dolgozhatnak a kampány üzenetének?

Integráció vagy dezintegráció

2014-ben az elemzés összességében egy erősen megosztott társadalom képét mutatta, amelyben kéthárom politikai csoportosulás verseng azon, hogy melyikük integrációs elvei érvényesüljenek a társadalomban. A parlamenti demokrácia közös nevezőjét nagyjából mindegyik párt elfogadta. A többpárti demokratikus választási rendszert, és az ezzel létrehozott parlamentet, mint a különböző érdekkifejezések találkozásához, szembesüléséhez, és összedolgozásuk lehetőségéhez közös intézményi keretet adó politikai közeget alapjaiban egyetlen számottevő politikai erő sem kérdőjelezte meg. S ameddig ez így van, amíg a többpárti választási rendszer és a többpárti parlament határozza meg az ország politikai életét, addig az ezekre a pillérekre épített politikai demokrácia valamilyen mértékú integrációs szerepet mindenképpen betölt. Ám ha az egyes pártok között nem egyszerúen érdekkülönbségek, értékrendi különbségek és ideológiai különbségek, hanem alapvető érdek-, értékrendszeri-, és ideológiai ellentétek feszülnek, ezek növekedése egyúttal a dezintegráló hatások erősödését is jelentheti.

A dezintegratív folyamatok akkor kezdenek elszabadulni, amikor az egyes politikai aktorok elkezdik megkérdőjelezni egymás legitimitását. Akár csak retorikai szinten is. Hiszen a társadalomra, a pártok választóira sokkal erősebben hat, amikor a pártok képviselői egymást „diktátornak”, „maffiózónak”, „bűnözőnek”, „országrontónak”, „összeesküvőnek”, „hazaárulónak”, stb. bélyegzik, mint az a tény, hogy ugyane képviselők azért képesek ugyanazon bizottságokban, magukat ugyanazoknak a (parlamenti) játékszabályoknak alávetve, egymás kollégáiként tevékenykedni. Az ellenfél politikusainak démonizálása a párt elkötelezett híveiben gyülö- 
letet szabadíthat fel ${ }^{4}$ nemcsak a megbélyegzett személyekkel, hanem egész politikai „családjukkal” szemben, s ez természetesen erős dezintegratív, a társadalmat (tartósan) megosztó hatás. A parlamenti politizálás (vagyis az intézményesült politikai demokrácia) integráló hatású közös nevezőjét felülírja az olyan dezintegráló társadalomkép, amelyben az integráció alapját képező rendszeregységnek (a nemzeti társadalomnak) egy része ellenségként tételeződik. Magyarországon a 2002-es választási kampány óta - a közvélemény nagy részének „békepártisága” ellenére-- egyre mélyültek a két fő politikai tábor közötti árkok, s ez annak ellenére folytatódott, hogy tudni lehetett, hogy egyfelől a túlságos polarizáció „harmadik erőknek” kedvezhet, s hogy másfelől az indulatok fokozódásából igazából a politikai mező legradikálisabb aktorai tudnak profitálni. A 2014-es kampányt is a túlfútött kölcsönös ellenségeskedés jellemezte; a nagy pártok egyáltalán nem törekedtek arra, hogy a közvélemény nagy részének kívánalmai szerint csökkentsék a végletes szembenállást. A gyúlölet megnyilvánulásait, (a „gyűlöletbeszédet”) legfeljebb a „másik” oldalán ítélték el. S úgy tűnik, ha egyáltalán rossznak tartják ezt a kiélezett ellenségeskedést, akkor szükséges, a mozgósítás érdekében felhasználható és felhasználandó rossznak tekintik. Márpedig az ilyenkor alkalmazott - és a pártérdekek érvényesítése szempontjából profeszszionálisnak számító, a tanácsadók által is előnyben részesített-- egyes eszközök önmagukban is gyöngíthetik a társadalom integrációját. A karaktergyilkosság például, amivel a pártok ellenfelük egyes „tisztjeit” igyekeznek leütni a sakktábláról, az adott pártot erősítő közvetlen hatása mellett - főként, ha e módszer alkalmazása gyakorivá válik - az egész „politikai osztályra” (és ezen keresztül az integráló demokratikus politikai rendszerre) visszaüt, az egész pártpolitizálással szembeni bizalmat áshatja alá. A mindenkori ellenzék számára látszólag magától értetődően kínálkozó eszköz a jelen állapotok negatív megítélése (vagyis az előző ciklus kormányzásának kritikája). Ám ha ez a kritika „depressziókampányba” megy át, mint a 2014-es „baloldali” ellenzék kampánya, vagyis azt sugallja, hogy minden rossz, ez egyrészt nem mozgósít, másrészt elidegeníti azokat, akik nem éreznek mindent rossznak, legfőképpen pedig éppen hogy az integrációt erősíteni képes, pozitív közös nevezőt nem kínál fel a társadalom számára 5 .

Persze az optimista kampány sem feltétlenül integráló hatású (hiszen azzal meg azok nem tudnak azonosulni, akiknek tapasztalatai nem erősítik meg az optimista állításokat), de a társadalomkép egészének pozitív képzetekkel való körülvétele elvben sokkal inkább alkalmas a társadalom integrációjának megvalósítására. Amikor a magyar történelmi hagyományok két-- visszahúzó - alapsajátosságaként szóba kerül a „széthúzás6” és a „pesszimizmus”, a magyar történelmi tudatnak a tragikus sorsfordulatokra - Lech-mező, Muhi, Mohács, Majtény, Világos, Arad, Trianon, '56 leverése - való felfüződése, sokan összefüggést találnak e két sajátosság között: nem csak abban, hogy a széthúzás sokszor elősegítette a tragikus kifejletet, hanem abban is, hogy a

4 A 2014-es választásokon a legdominánsabbnak mutatkozott három nagy politikai erő mindegyikének szavazótáborában - és értelmiségi holdudvarában is - kifejezetten premodern jellegú gyűlölködések, de legalábbis szélsőségesen intoleráns ítéletek váltak szinte mindennapossá.

5 A tömegkommunikáció tudományában ma már több elmélet (agenda setting, „hallgatás spirálja”, „gonosz világ” stb.) által is megfogalmazott evidenciának számít, hogy amit a nyilvánosságban megjelenítenek, az visszahat a társadalom tudatára. Ha a társadalom azokkal az üzenetekkel szembesül, hogy az a világ, amiben él, rossz, akkor (legalábbis a társadalomnak a tömegkommunikációs üzenetek által befolyásolható része) saját tapasztalatait is ebbe az irányba fogja rendezni, s mint „bizonyára nem jellemzőeket" elnyomja az ennek ellentmondó tapasztalatait. A „rossz világban élünk” közérzete azonban tovább növeli a bizalmatlanságot, a konszenzuskeresés helyett az ellenséges indulatokat, vagyis alapjában dezintegratív hatású.

6 Amit a hagyományban „török átokként” is emlegetnek (és valóban van köze a történelem törökkori, végletesen megosztó alakulásához). 
tragikus nemzeti önkép gyengíti a társadalom integrációját. Azokban az országokban, ahol a nemzeti önkép pozitív képzetek köré szerveződik, jóval megalapozottabb tud lenni a társadalom integrációja is. A nemzeti büszkeség előtérbe kerülése/helyezése az integrációt az esetek nagy részében erősítheti. A kormányoldal - saját sikereinek alátámasztására - használta is ezt a stratégiát: „a magyar emberek eröfeszitéseinek köszönhetően Magyarország ma már saját lábán áll. Sok mindenre lehetünk büszkék.” "Magyarország nem hagyja magát!” stb. Az ilyen és ehhez hasonló (a plakátokon és szórólapokon ismétlődő) szlogenek az ország/nép egységes alanyként való szerepeltetésével integratív hatásúak lehetnek. Ezt a hatást azonban rombolhatja, ha a politikai ellenfeleket - s ezzel az ország/nép egy részét - lényegében kizárják ebből az egységből. Egyfelől megjelennek olyan nyilatkozatok, megfogalmazások, amelyek hangsúlyozzák, hogy a közös sikerekben mindenki benne van, az ellenzék támogatói is, másfelől, amikor az ellenzéknek nem csak egyes képviselőit minősítik elfogadhatatlannak, hanem az egészet bélyegzik gyakorlatilag „búnszövetkezetnek” és egyszersmindenkorra bukottnak, ezzel egyszersmind meg is akadályozzák az e pártok mögött álló jelentős számú csoportok integrálódását a „nemzeti egységbe".

Persze, a (rövid távú) politikai ráció ebből a szempontból nem feltétlenül „békepárti”: régi szociálpszichológiai tétel, hogy a közös ellenség növeli a csoportkohéziót, tehát a saját táboron belül integráló hatású. ( $A z$ ellenségeskedést viszont eszkalálja: amikor az egyik csoport „összezár”, ez aktivizálja az ellenfeleket is, és így tovább. A társadalom egésze mindennek következtében egyre jobban dezintegrálódhat). Itt megint az a kiinduló állítás kaphat megerősítést, hogy a különböző rendszerszintek integrációs érdekei összeütközésbe kerülhetnek egymással. Ehhez azonban azt a másik fenti állítást próbáljuk hozzákapcsolni, hogy egyik rendszerszint stabil integrációja sem lehetséges a többi rendszerszint integrációs elveivel való összehangolódása nélkül. Egyrészt a felsőbb szint eredményes integrációjának feltétele, ha kapcsolódni tud az alsóbb szint integrációjával. (Ez az elemzett esetben azt jelenti, hogy a felsőbb szint „közös nevezőjének” - a nemzeti konszenzusnak - tartalmaznia kell azokat az értékeket, amelyek az alsóbb szintú rendszeregységek - esetünkben az egyes politikai szubkultúrák - pozitív összetartó értékei). Másrészt, hogy stabilizálódhasson, az alsóbb szintű rendszeregységek mindegyikének legalább potenciálisan összhangba kell hozni a maga belső integrációját az „egész" integrációs elveivel (vagyis a belső integráció nem alapulhat ${ }^{7}$ a nagyobb egység többi alkotóelemével való ellentéten). Ha ugyanis a különböző rendszerszintek között nem történik meg ez az összehangolódás, ez nem csak a felsőbb szint integrációját teszi lehetetlenné, de előbb-utóbb az alsóbb rendszerszint dezintegrációjához is vezet ${ }^{8}$.

Elvben mindezzel tisztában vannak a társadalom aktív szereplői. A parlamentáris demokráciában elvben a legtöbb politikai erő integrációra, az egész társadalom integrációjára törekszik. Persze ehhez mindegyik a maga értékeit kínálja fel közös nevezőnek. A probléma csak az, hogy többnyire kísérletet sem tesznek arra, hogy a többiek értékeit tolerálva valóban közös nevezőket keressenek. A jelszavakban éppen az ellentétek fokozódása idején (nyilván a közvélemény elvárásaira is reagálva) felszaporodott az „együtt”, az „összefogás”,

7 Ez azt jelenti, hogy természetesen lehetnek ellentétek, minthogy semmilyen társadalom nem képzelhető el érdekellentétek nélkül, s az emberi lehetőségek kibontakozása szempontjából egy homogén társadalom egyáltalán nem is kívánatos, de egy stabilan integrált társadalomban az alrendszerek öndefiníciója, identitása, összetartása nem alapulhat a rivális csoportok tagadásán.

8 Számtalan történelmi tapasztalat igazolja, hogy az ellenségképen alapuló csoportidentitás előbb-utóbb belső ellenségkereséshez, bizalmatlansághoz, a saját tábor "leszalámizásához” is vezet.

9 Jellemző, hogy ezzel a névvel mind a két oldalon megjelent egy-egy politikai alakulat... 
a „közösen” hangsúlyozása, a gyakorlatban azonban ez a „közös” nem csak a politikai ellenfelekre nem terjed ki, de gyakran a saját oldali szövetségesekre sem ${ }^{10}$. Az egymás iránti bizalmatlanság, a szinte teljes kooperációképtelenség hitelteleníti ezeket a jelszavakat, (és a pártokhoz nem kötődőkben tovább csökkenti a politikai intézményekbe vetett bizalmat). Az „oldalak” közötti közös nevező keresése (ha csak szavakban is) a 2014-es kampányban legfeljebb a kisebb pártokra volt jellemző ${ }^{11}$. (A kisebb pártoknak azonban nem volt számottevő hatása a politizáló társadalomra, egy részük pedig ráadásul nyilvánvalóan éppen azért jelenhetett meg, hogy tovább gyengítse egyik vagy másik politikai oldal támogatóinak összetartását).

A tartósodott ellenségeskedés légkörében minden átpolitizálódik, ennek következtében a legkülönfélébb kérdésekben (az oktatásügytől a színházak igazgatásáig, a romák helyzetéből adódó problémák megoldásától a munkaerő-áramlásig) pártálláspontok ütköznek egymással, a polarizáció miatt rendszerint két rossz véglet formájában: a köztes, hatékony megoldások, a különböző álláspontok előnyeit, relatív igazát egyesítő szintetikus megoldások nem is jelennek meg a diskurzusokban. ${ }^{12}$

Az intoleranciához, a gyúlöletbeszédhez hasonlóan dezintegratív hatású a „kettős mérce” alkalmazása is. A társadalom bármely szintjén csak az adott szint egészében érvényesülő egyenlő mérce alkalmazása válthat ki integratív hatást, csak ez erősítheti meg azt a tapasztalatot, hogy valóban vannak közös, mindenkire egyaránt érvényes elvek, amelyeket az aktuális hatalom képviselői nem csak ellenfeleikkel, hanem önmagukkal szemben is érvényre juttatnak. A törvények többnyire ilyen egyenlő mércén alapulnak, azonban az, hogy ezek integratív hatása létrejön-e vagy éppen dezintegráció lesz a vége, azon múlik, hogy a törvények érvényesülését mindig érzékenyen figyelő társadalom mit tapasztal. Ebből a szempontból a hatalmon lévőknek önmagukkal szemben mindig szigorúbban kellene eljárniuk, azért. hogy az egyenlő mérce alkalmazását a közvélemény érzékelje. A korrupció, a gazdasági hibák és erkölcsi gyöngeségek számonkérése az ellenféllel szemben hitelét veszti, ha ugyanezek a hatalmon lévőknek is felróhatók, s ez természetesen azt is megakadályozza, hogy a társadalom egésze a hatalmat (s az általa betartatni próbált törvényeket) integráló erőként ismerje el. Ebben természetesen mindig a hatalmon lévők felelőssége nagyobb, hiszen az adott időszakban nekik kell a törvényeket betartatniuk). A 2014es kampányban is az volt a jellemző, hogy a nagy pártok általában a kettős mérce szerint jártak el: hevesen támadták különböző vonatkozásokban ellenfeleiket, s amikor ugyanazok a vádak velük szemben hangoztak el, igyekeztek ezeket bagatellizálni, illetve teljesen más szempontok szerint megítélni. Természetesen az ellenfél elmarasztalása, és a saját magatartás mentegetése megfelel a (rövidtávú) politikai racionalitásnak, amely szerint mindenkinek értékesebbnek, kiválóbbnak kell mutatkoznia, látszania versenytársainál, csak ilyenkor az vész szem elől, hogy a kettős mérce alkalmazásával - mihelyt ez kiderül - éppen ez a látszat foszlik semmivé (nemcsak a „másik oldalon” lévők, hanem a kívülről szemlélők, illetve az adott értékeket komolyan vevők megítélésében

10 A „baloldali koalíció” majdnem az utolsó pillanatig az egymással való vetélkedésről szólt.

11 A JESZ például az alábbi szöveget tette közzé: „Legendás volt, hogy a Batthyány kormány két minisztere, Széchenyi István és Kossuth Lajos mennyire ki nem állhatták egymást, ennek ellenére tudtak együtt dolgozni az ország érdekében! Hiszünk Batthyány és Gandhi példájában, akik képesek voltak egy társadalmat minőségileg megújítani, mert hittek a szeretet és az összefogás erejében". (JESZ szórólap)

12 Erre ráerősít (a politika mediatizációja következtében a politikai életre egyre nagyobb hatást gyakorló) média is, amely „a közönségérdeklődés fenntartása érdekében" az álláspontok kiélezését, dramatizálását preferálja. 
is $\left.{ }^{13}\right)$.

\section{Negatív kampány}

A kampány „élethalálharccá” élesedését már a 2006-os kampányban lehetett észlelni. Az utolsó békésebb kampány 1998-ban volt. Ekkor még csak a MIÉP próbálkozott a „totális háborúval”. 2002-ben a negatív kampány már a pártpolitikai küzdelem fő frontvonalára került ${ }^{14}$, és attól fogva egyre hevesebben, valóban szinte „élethalálharccá” fokozódott ${ }^{15}$. Korábbi elemzéseinkben a felfokozott indulatokat egyrészt a pártpolitika kétpólusúvá válásával, másrészt a választótáborok rendszerszintű történelmi megosztottságával (az 1948-as ill. az 1990-es rendszerváltások vesztesei), illetve a gazdasági-társadalmi felzárkózás egymással antagonisztikus ellentétben álló, és szintén történelmi gyökerű két koncepciójával (reformkor-modell versus Gründerzeit-modell) próbáltuk értelmezni. Az akkori következtetéseket lényegében ma is érvényesnek tartjuk.

A polarizáció néhány szocio-kulturális összetevőjéhez ${ }^{16}$ „a konfrontáció „kultúrharc” jellege (...) elsősorban olyan magyarázatok keresésére sarkall, amellyel éppen ezt a kétpólusú szerkezetet lehet kulturális mögöttes struktúrákkal megmagyarázni.

\section{Mi van a két pólus mögött?}

A pártok önmeghatározása ebben nem sokat segít. „Baloldal” és „jobboldal” áll egymással szemben, de e fogalmaknak sem klasszikus meghatározásai, sem azok ellentéte nem alkalmas az adott viszonyok leírására. A hagyományos, a társadalmi egyenlőtlenségek leküzdésére, az alsóbb helyzetű csoportok érdekeinek védelmére szerveződött baloldal az államszocializmus során hatalomra kerülvén egy olyan társadalmi rendszert épített ki, amelyben új társadalmi egyenlőtlenségek jelentek meg, s miközben a „baloldali”, „kommunista” pártok „hívei” továbbra is az eredeti értékeket társították mozgalmukhoz, a pártok hatalomba került képviselői és hatalmi gyakorlata következtében sokak szemében ezekhez a fogalmakhoz a diktatúra, a politikai despotizmus, (s a hozzá csatlakozók egy részének tipikus magatartása folytán az elvtelen karrierizmus) majd a hatalom átkonvertálásakor a korrupt harácsolás és egy sajátos újtőkés „osztály”17 képzetei társultak. (Mindezek hagyományosan

13 S mivel a „saját oldalon” is vannak, akik az értékeket komolyan veszik, a kettős mérce olykor a saját táboron belül is lehet dezintegratív hatású. Hatékony propaganda ezeket a hatásokat, (a kettős mérce okozta következetlenséget) persze elfedheti, (s ezzel csökkentheti a dezintegráció veszélyét is), tökéletesen hatékony propaganda azonban hosszú távon nem létezik.

14 Már ekkor lehetett tapasztalni a párbeszéd-képtelenséget; a kölcsönös vádakat: korruptak, demokráciaellenesek, illetve a kommunisták örökösei, a nemzetközi pénztőke képviselői -a kampány erősen átdramatizálódott, növekedett az intolerancia, megjelent a rémhírpszichózis, széles körben terjedtek a hírek választási csalásokról, és a demokrácia intézményeibe vetett bizalom általános gyengülése volt megfigyelhető.

15 Ezt erősítette a kampányok időtartamának hosszabbodása. A 90-es évek végétől már az egész utolsó év kampányidőszak volt; 2002-ben azt állapíthattuk meg, hogy még hosszabb lett a kampány, mert már karácsonytól elindult. 2006-tól viszont gyakorlatilag az egész kormányzati ciklus kampányidőszakká vált, folyamatos ellenzéki demonstrációkkal a kormánnyal való elégedetlenség becsatornázására, az ellenzéki erő felmérésére, összetartására. 2013-ban már a köztársasági elnök próbálta mérsékelni ezt a tendenciát, felszólítva a pártokat, hogy legyenek visszafogottabbak a kampányban és az ország valós problémáival foglalkozzanak. A kampány-eszkaláció megállíthatatlannak tûnik: a 2014-es parlamenti választások végeredménye még nem született meg, amikor már megkezdődött az EP-kampány. A hosszú kampány következménye, hogy a vallásháborúk módján szívja magába, politizálja át, s teszi kultúrharc tárgyává az olyan kérdéseket is, mint a színházigazgatások, a Magyar Múvészeti Akadémia, a felsőoktatási keretszámok stb.-- amelyeknek egyáltalán nem szükségszerű pártpolitikai kérdésekké válniuk.

16 Az itt következő alfejezet Értékválasztás 2002 címú tanulmányunk részlete.

17 ... és a szovjet világbirodalom kialakulásával a nemzeti elnyomásnak szintén a hagyományos baloldalisággal ellentétes képzetei is. 
ellentétesek a „baloldalisággal”). A szocialista párt „megörökölte” mind az eredeti baloldali értékekben hívők csoportjait, mind az államszocializmus hatalmából részesedett személyeket, mind pedig a pártállami apparátus szervezeti logikáját, s a hozzá kapcsolódó új tőkék vonzáskörében más tőkés csoportok bizalmát is magához társította. Mindezek következtében mint párt a hagyományos értelemben vett baloldali és jobboldali elemek kusza keverékének tekinthető. A „jobboldal” nagy része egyértelmúbben viseli magán a hagyományos jobboldaliság olyan jegyeit, mint a konzervativizmus, a tekintélyelvhez való vonzódás, az egyházakhoz fűződő jó viszony, a nemzeti retorika. Ugyanakkor a morálisan „jobboldalivá” vált államszocializmus olyan ellenzői is csatlakoztak a szocializmus természetes ellenfeleként fellépő hagyományos „jobboldalhoz”, akiket éppen a hagyományos baloldali értékek: a szolidaritás, az egyenlő esélyek, az igazságosság, az emberség hiánya fordított szembe a „kommunisták” hatalmával. Így a jobboldali pártoknál meg a hagyományos jobboldaliság keveredik egyfajta „baloldalellenes” baloldalisággal: a fogalmak és értéktartalmaik nem fordultak át ellentétükbe, de teljesen összekavarodtak.

Nem alkalmas értelmezésre a pártok önmeghatározása sem. Ráadásul ez is állandó mozgásban van. Az egyik tábor „polgárinak” nevezi magát, ami a szocializmus értékrendjével szembefordított, ezért a szocializmustól való elhatárolódásra alkalmas kategória, ugyanakkor használatmódjában összemosódik (a magyar szóban eredetileg is egybekapcsolt) „bourgeois” és a „citoyen”; s nem ad támpontot arra nézve sem, hogy a polgárosodás melyik útját képviseli (ezért alkalmas egymástól különböző, vagy egymással akár ellentétes törekvések befogadására is). Ugyanakkor a „polgárit” a másik oldal is értéknek ismeri el, tehát az önmeghatározás a másik oldal szemében nem jelent megkülönböztető sajátosságot. Ugyanez a helyzet a „nemzeti pártok” önmeghatározással is. Bár egyes konkrét kérdések kezelésében eléggé jól különválik a két tábor értékrendje, s ennek alapján annyit esetleg lehet állítani, hogy a nemzeti kérdések iránt talán hagyományosan valamivel nagyobb illetve többekre jellemző érzékenység van az egyik oldalon, mint a másikon. Ha azonban a „polgári oldal” magát a „nemzetivel” azonosítja, ez nemcsak azt jelenti, hogy kirekeszti a „nemzeti” fogalmából a nemzet kisebb vagy nagyobb felét - akik ezt természetesen nem fogadják el -; hanem önellentmondáshoz is vezet, hiszen az empirikus nemzetet a társadalom egésze alkotja, nem lehet valaki a „nemzet” képviselője úgy, hogy csak egyik részét képviseli. A másik oldal - erre való reakcióként is - „nemzeti középnek” kezdte magát hívni, ami megint csak használhatatlan önmeghatározás, mert ugyan kifejezi azt, hogy már nem „baloldali” erőről van szó, - ezzel mellesleg végképp összezavarva szavazóinak azon részét, akik továbbra is baloldali vonzalmaikat vetítik a pártra -, de egyáltalán nem tájékoztat arról, hogy mihez képest (mi között) van „középen”; ráadásul amikor két nagy táborra oszlik a politikai mező, akkor értelmetlen az egyiket „középnek” nevezi. Ha mind a kettő az, akkor még inkább.

A két tábor kulturális preferenciáit tekintve a fentieknél talán egy fokkal használhatóbb a konzervatívmodernista megosztás. A hagyományok értékvédelme és a haladás kultusza sok konkrét döntés, sok konkrét ízlésítélet esetében ütközik. (Az étkezési szokások konzervativizmusától-nyitottságától a lakásmód, a szórakozás, a vásárlási szokások, az autóhasználat és a mindennapi élet megannyi egyéb mozzanatán át a nevelési szokásokig, vagy éppen az iskolaválasztásig, hiszen például igen jól különválik az egyik oldalon az egyházi iskolák, tekintélyelvű iskolák, a másikon az alternatív iskolatípusok és a „versenyistállók” preferálása). A választók jelentős része konzervativ illetve modernista beállítódása alapján evidenciának tekinti, hogy melyik oldalra kell 
voksolnia. A kampányból is kiemelhetünk ${ }^{18}$ olyan elemeket, amelyek alapján azt mondhatjuk, hogy például az egyik oldal kampányfilmjeiben több a hagyományokra, a másikéban több a modernizmusra utaló elem. Azonban ez a felosztás is félrevezető leegyszerűsítés lenne. Mivel mindkét oldal „néppártiságra” törekszik, jelentős erőfeszítéseket tesznek önmaguk sztereotip besorolásának feloldására. Az MSZP például olyan, a konzervatív oldalon szokásos szimbólumokra épít, mint a családi biztonság, a falu, a templom; a legkorszerúbb popzenére táncoló fiatalokat, a modernség technikai szimbólumait meg inkább a másik oldal filmjeiben látjuk. A FIDESZ eleve jóval fiatalabb, a haladás legújabb áramlatai felé nyitott tömegbázisa akkor is legalábbis ambivalenssé teszi a fenti szempontból e párt arculatát, ha ezek a fiatalok - a korszakban felerősödött értékrendszernek megfelelően - föleg konzervatív értékekhez igyekeznek igazodni.

A két tábor megoszlását szemlélve óhatatlanul felmerülhet az emberben az a „kettős társadalom” modell is, amellyel Erdei Ferenc jellemezte a két világháború közti Magyarországot. (Feltételezve, hogy a társadalomban egymás mellett és egymással is szembesülve két párhuzamos társadalmi struktúra él; egy /poszt/feudalizmus úr-paraszt világa és a kapitalizmus burzsoá-proletár ellentéte, ahol mindkét ellentétpár tagjai éles ellentétben vannak egymással, de ugyanakkor együtt mégis közös kulturális mezőt képeznek a másik párossal szemben. A két struktúrában más-más logika uralkodik; az egyikben a személyi függések évszázados hagyományokra építő, a másikban a pénzviszonyok logikája.) Az egyes ember, attól függően, hogy melyik struktúra tagja, illetve melyikhez szocializálódott, egészen különbözően viszonyul a világ szinte minden jelenségéhez. E megoszlás sok tekintetben párhuzamos a konzervatív-modern megoszlással, a falu-város, vidék-főváros megoszlással, (s tartalmazza a zárt-nyitott, közösségi-individualista dichotómiák elemeit is), de egyikkel sem azonosítható teljesen. Bizonyos, hogy a jelenlegi kettétagolódásban (az értékekben, az ízlésben, az érintkezési formákban, a stílusban) e kettős struktúra nemzedékről-nemzedékre örökített hagyományai is szerepet játszanak, de a jelen viszonyokat már csak azért sem lehet pusztán ezekből levezetni, mert a kettős struktúra - ha lelki vetületei továbbéltek is - a szocializmus idején nagyrészt felszámolódott, átszíneződve beépült a szocializmus bürokratikus szerkezetébe, és annak szétesése után már nem az eredeti formában rekonstruálódott. ${ }^{19}$

Mi van akkor helyette? Mi hát az a társadalmi kettősség, ami a politikai kettéválásban kifejeződik? Véleményünk szerint a polgárosodás két útja, (amelynek köze van a múlt említett kettős társadalmához, de nem azonos azzal).

A polgárosodás a 19. században két nagy hullámban érintette meg a magyar társadalmat. Az első hullám a századeleji mezőgazdasági konjunktúrára alapozva a nemesség és parasztság polgárosodásának kísérlete volt a reformkorban - ezt erőszakosan megtörte a szabadságharc bukása. A második hullám a század végén a nemzetközi ipari és banktőke behatolásával az úgynevezett „Gründerzeit”-ben következett be, egy mind a nemzetközi tőkétől, mind pedig a bürokratikus államgépezettől függő (jelentős részben nem-magyar eredetű) polgárság megjelenésével (ezáltal alakult ki az említett kettős társadalom). A 20. században az első (a magyar gazdaságból szervesen kinövő) polgárosodási modell felélesztésének kísérlete volt a népi mozgalom, ám ennek

18 Mivel ez a szövegrész az Értékválasztás 2002 címmel 2003-ban megjelent tanulmányunkból származik, itt értelemszerűen a $2002-$ es kampányról van szó.

19 Az Antall-kormány alatt éppen az vált világossá, hogy az egyik (a „posztfeudális”) struktúra eredeti formájában már nem létezik. (Legfeljebb egyes, családi szocializációban átörökített nosztalgiák.) 
lehetőségeit a második világháború után az államszocializmus felszámolta. Az államszocializmus - antikapitalista indíttatásának megfelelően -- ugyanakkor szembehelyezkedett a másik, az „urbánus” úttal is. Történetének utolsó szakaszában a piacgazdaság felé tájékozódva azonban a „szocializmus” egyszercsak "felfedezte” a Gründerzeit értékeit, és a korabeli gazdasági szakemberek és történészek a polgárosodás ezen hagyományát „aranykorként” igyekeztek rehabilitálni. Ez nem választható el attól a folyamattól, ahogy a szocializmus elitjének egy része megindult a tókéssé válásnak - a 19. századvégihez hasonlóan - nemzetközileg függő, a banktőkére és a bürokratikus államgépezetre támaszkodó változata felé. A rendszerváltás után a polgárosodás két útja ismét előállt. Igen széles tömegek az államhoz kapcsolódóan ${ }^{20}$ (és nemzetközi kapcsolatokra is nyitottan ${ }^{21}$ ) a „szocialista” módon kezdtek illetve próbálnak „polgárosodni”22; ezért nem csak politikailag, hanem kulturálisan is ahhoz a polgárosodási modellhez vonzódnak, amit főként az MSZP-hez lehetett társítani. Másfelől viszont a privatizációval megjelentek olyan tőkefelhalmozási lehetőségek is, amelyek a magyar gazdaság belső folyamataiból tudnak kinőni, s e tekintetben jobban hasonlítanak a 19. század első, reformkori hullámára, mint a másodikra. Ez indokolja a reformkor „reneszánszát”, s főképpen azt a kulturális kettétagolódást, ami az ország lakosságának egyik felét (az egymáshoz hasonuló) nemzetközi tőkeérdekeltségű-urbánus és szocialista polgárosodás, a másikat viszont ${ }^{23}$ a belső gazdasági forrásokra támaszkodó „reformkori típusú” polgárosodás logikája, értékrendje, világlátása - és politikai preferenciái - felé hajtja. Ez van javarészt a „nemzeti” problematika mögött is, áthatva persze a polgárosodás különböző útjaiból következő eltérő érdekeken kívül sok egyéb érzelmi, indulati tényezővel és megfontolással is". (Kapitány-Kapitány 2003: 143-148)

2008 óta az gazdasági világválság hatásai, az életminőség sok tekintetben érzékelhető romlása, százezreknek az adósságcsapdába kerülése stb. továbberősítették ezeket az indulatokat, amelyeket mindkét oldal igyekezett a másik oldal felelősségével összekapcsolni. A pártok propaganda-apparátusa a 2014-es kampányban is épített ezekre az indulatokra, és arra a felfogásra, mely szerint a választások tétje nem egyszerǔen parlamenti pártok váltakozása a hatalomban, hanem rendszerek ütközése, illetve az ellenfél pártjaiba szerveződött (egységesnek tekintett) erők, mintegy a „Gonosz” támadása a „Jók” ellen. A hidegháborúból nemzetközi szinten ismerős képlet fekete-fehér szemlélete mindkét oldal propagandamunkáját áthatotta, s ebben a leegyszerúsí-

20 Elsősorban különböző állami forrásokhoz, megrendelésekhez kapcsolódva, az államapparátusbeli személyi kapcsolatokat kihasználva, majd a privatizáció során sokan az állami vagyon egy részének magukhoz vonásával. Ha figyelembe vesszük, hogy mindez nem csak „nagyban” (mind erősebb vállalkozások formájában), hanem „kicsiben”, (protekciók igénybe vételével, bedolgozással, állami támogatásokra, hitelekre épített vállalkozásokkal) is zajlik, akkor beláthatjuk, hogy valóban eléggé nagy tömegeket érintő „felhalmozási” modellről van szó.

21 A „,nemzetközi” nyitottság az egyes emberek számára egyrészt a különböző külső kulturális hatások gyors átvételét jelenti, másrészt megnyilvánul olyan jelenségekben is, mint a rendszerváltás előtt és után tömegesen zajlott „,bevásárlószatyros” kereskedelem (a KGST piacok tevékenységétől az ausztriai hűtőláda-, és isztambuli aranyékszer- turizmusig), mely utóbbinak elősegítője (s következménye is) lehet a kulturális nyitottság növekedése.

22 Itt nem csak valóságos polgárosodásról van szó. A leszakadó tömegek sehogyan sem tudnak polgárosodni, de egy paternalista jóléti államtól olyan mentőöveket várnak, amelyek - például a nyugati szociáldemokrácia jóléti társadalmaiban - kulturális értelemben a változások veszteseit is beemelik egy polgári társadalom mindenkire (vagy csaknem mindenkire) kiterjedő keretei közé.

23 Persze a két út szétválása egyáltalán nem éles határok mentén történik. Minthogy leginkább ezek voltak adva az államszocializmus összeomlása után, így az inkább a „,belső” típusú úthoz köthető „polgári”, „jobboldali” erők is gyakran és a hatalom birtokában mindinkább az állami bürokrácia jellegzetes (posztkommunista) mechanizmusaira vagy a banktőkére (is) támaszkodva próbálják megalapozni felemelkedésüket. 
tett modellben a két legnagyobb politikai csoportosulás egyike sem fordított figyelmet „,harmadik” szereplőkre. A Jobbik „MSZP $\times$ Fidesz = megszoritás ${ }^{2 \prime}$ plakátjával (s főleg parlamenti és médiaszerepléseivel) már jóval a választások előtt definiálta magát harmadik és mindkét nagy pártszövetséggel szembenálló erőként ${ }^{24}$. Majd az e szembenállást kifejező, két versenytársát elnyomónak és tolvajnak minősítő negatív kampánygesztust letudva a tényleges kampányidőszakban a kampányfilmek-plakátok szintjén szakított a negatív kampánnyal, és saját -- sokak számára túl-radikális-- imázsának szelídítésével igyekezett bázisát tovább szélesíteni²5. Ez a tendencia azóta csak fokozódott. A két nagy politikai erő az egymással szembeni negatív kampány stratégiáját folytatta -- nem egyenlő esélyekkel és nem azonos eszközökkel. Az ellenzék elhibázottnak minősítette a kormánypártok gazdaságpolitikáját, és a kampányban e gazdaságpolitika fontos lépéseinek visszafordítását helyezte kilátásba: összességében egy olyan programot sugallt, ami a közvélemény számára inkább a 2010 előtti időszakhoz való visszatérést ígérte, mint új koncepciót. Miután az előző kormányzat a 2010-es választásokon igen széleskörú elutasításban részesült, az ebben a programban megfogalmazott szimbolikus üzenet aligha számíthatott többségi támogatásra. Ugyan voltak ebben árnyalatbeli különbségek a korábbi kormányerők bomlásából keletkezett ellenzéki pártok között, de lényeges újítás egyikhez sem kapcsolódott, s a különbségek csak a megosztottság, az egymással való marakodás érzetét erősítették. Az ellenzék másik fő választási témája, szimbolizációja a kormány centralizációs és egyéb intézkedéseinek „diktatúraként” való támadása volt. A negatív kampány logikája szerint e támadások egyre élesebb formában fogalmazódtak meg, a negatív kampány azonban visszaütött: a közvélemény nagy része a centralizációs intézkedések többségét nem érezte annyira tragikusnak, szélsőségesnek, mint ahogy azt az ellenzék igyekezett beállítani. A kormányoldal a negatív kampányt több síkon tudta folytatni. Egyrészt a pártjuk jogfolytonosságát vállaló szocialistákkal szemben a rendszerváltás óta mindig mozgósítani lehetett a „kommunizmus” visszatérésétől tartók szorongásait, másrészt, még frissen éltek az előző kormányzattal kapcsolatos, a lakosság nagyobb részében inkább negativ érzelmek, s rendszeresen figyelmeztetni lehetett arra, hogy „ez az, ami 2010-ben megbukott”. Harmadrészt, a megtervezett ütemezésben napvilágra hozott különböző korrupciós ügyeket jól lehetett használni arra, hogy egy negatív kampányban az ellenfél egészének tisztességtelenségét sugallják.

A pártok közti ellentétek és ütközések természetesek egy olyan szerkezetben, amely a különböző erők versenyén alapszik. A mondandóját dramatizáltan előadó hatása nyilván nagyobb, mint azé, aki pusztán ismer-

24 Az LMP is harmadik erőként igyekezett magát megjeleníteni, de az erre irányuló erőfeszítéseket majdnem megsemmisítette, (és az LMP-nek a „harmadik erő" szerepéért folytatott versenyfutásban való lemaradásához vezetett) az ezt a szerepet nem vállalók elutasítása, majd az ezt követő pártszakadás.

25 Az olyan eszközökben, mint a párt saját kiadású lapja, ahol szintén nagy hangsúlyt fektettek a pozitiv kampány felépítésére, azért megjelentek a negatív kampány jellegzetes elemei is. Annak a szerepnek megfelelóen, miszerint a Jobbik mindkét nagy párt ellenfele és kihívója, úgy építettek a kormány támogatóinak az ellenzéki pártok teljes vezérkarát a pellengérre állító, azokat bûnözőként beállító plakátjára, hogy ezekhez hozzákapcsolták (az ellenzék által a „maffiakormány” megtestesítőiként beállított Orbán Viktort és Simicska Lajost), vagyis egyszerre használták fel, vitték tovább a két nagy párt egymás elleni támadását, és sugallták azt, hogy azok lényegében ugyanazt képviselik (tehát igazi alternatívát csak a Jobbik jelenthet). A párt által középpontba helyezett témákat erős érzelem-, és indulatkeltő túlzásokkal exponálták: „a magyar föld kiárusitása felér egy atomrobbantással”, „24 év leforgása után a 24. órában vagyunk; 24 éves háború folyik”. A párthoz kötődő rendpárti alapállás igen erős tematizációt kapott, s ezekben, a közvélemény jelentős részének támogatását vélhetően élvező kérdésekben jelentek meg az igazán radikális kifejezések és programok. „Nem lesz kegyelem az idősek, nők, gyerekek bántalmazóinak”; a pedofilek, nemi erőszaktevő́k kémiai kasztrálása, a halálbüntetés visszaállítására kezdeményezendő népszavazás stb. A „cigánybúnözés” explicit emlegetése csökkent, (közvetett célzások jócskán maradtak, például a „megélhetési gyermekvállalás” elutasításában), viszont „a cigány-magyar együttélés” jelszó megjelenése a pártot elfogadók körének szélesítését szolgálhatta. 
teti az álláspontját. Az ütközés erőpróba is, az erő mutatása pedig nélkülözhetetlen a politikai mezőben, ami a hatalom megszerzéséről szól: a hatalom mindig a nagyobb erő felmutatójának a „jutalma”. Sem a dramatizáció, sem az erő mutatása, sem az ütközés nem hozza magával azonban szükségképpen a negatív kampány alkalmazását. Ütköztetni egymással pozitív programokat is lehet. A negatív kampány nem annyira a saját erő demonstrálásáról, mint az ellenfél gyengítéséről szól.

\section{A negatív kampány megítéléséhez}

A negatív kampány alkalmazásának értékelésében a szakértők véleményei erősen megoszlanak.

Van, aki szerint (pl. Ansolabere-lyengar 1995) a negatív kampány elsődleges célja az elkötelezett hívek összetartásának erősítése. Lemondva a semlegesekről, bizonytalanokról, akiket a negatív kampány inkább eltaszít, a saját hívek elszántságát próbálják az ellenfél démonizálásával növelni. Minthogy a negatív kampány keltette rossz érzések a bizonytalanokat tovább távolítják a politikától, s a negatív kampány leleplezése (mint a politika „piszkos” módszereinek kritikája) tovább csökkentheti a választási részvételt (Ansolabere-lyengar 1995:10), a választók így (némi túlzással) nagymértékben az eleve elkötelezettekre szúkülnek le, amiből az következik, hogy ez az egész folyamat inkább előnyben lévő politikai aktorok számára kedvező ${ }^{26}$. A hivatkozott szerzők szerint a negatív kampány nem hatékonyabb a pozitívnál, arra azonban mindenképpen alkalmas, hogy kivédje az ellenfél negatív kampányát, akit, mire saját támadását megindítja, már hiteltelenné lehetett tenni (Ansolabere-lyengar 1995:15).

Mások eltérő módon vélekednek (pl. Dingfelder 2012, Brader 2005). A negatív kampány keltette félelem szerintük növeli a hatékonyságot, mivel erősebb hatást biztosít, mint a pusztán pozitív képzetek mozgósítása. Szerintük - az előző véleménnyel ellentétben - akkor érdemes negatív kampányt folytatni, amikor egy politikai erő némi hátrányban van, hogy ezáltal jelezzék azokat a veszélyeket, amelyek az ellenfél győzelmétől várhatók, az előnyben lévőnek pedig az a kedvező, ha a büszkeség és lelkesedés pozitív érzéseivel „betonozza be” a helyzetét. A bizonytalanokra gyakorolt negatív hatás ebben a felfogásban az ellenféltől való távoltartásuk előnyével jár.

S vannak, akik szerint a negatív kampány-hatás nem igazán jelentős a választói döntések szempontjából, illetve nagy mértékben függ a körülményektől (pl. Green-Gerber 2004, Niven 2004).

A hatások körülményfüggőségével mindenképpen egyetértve mi - nem lévén politológusok - nem kívánunk állást foglalni a negatív kampány hatásosságának kérdésében, (bár a politikai bölcsesség szempontjából a negatív kampány racionalitását megkérdőjelezi, hogy a politikában bármikor előállható kompromisszumkényszer, amely olykor még a „nagykoalíció”-kötést is elkerülhetetlenné teszi, erősen hitelteleníthet egy olyan pártot, amely kényszerú koalíciós partnerét korábban a Gonosz megtestesülésének bélyegezte). Értékszociológiai szempontból azonban az eldurvuló negatív kampány kártétele igen súlyosnak látszik.

26 Ehhez kapcsolható az a koncepció, miszerint a kormányon lévő pártoknak általában kedvező, ha félelemkeltő események történnek (vagy ilyenek veszélye valószínúsíthetó); ilyenkor a társadalom jelentős része felsorakozik a kormányzat mögé (rally around the flag effect). Persze ez sem abszolút törvény, nagy mértékben függ attól, hogy a közvélemény az eseményben (illetve a fenyegetésben) érzi-e a kormányzatnak is felelősségét. 


\section{A negatív kampány alkalmazásának néhány 2014-es példája}

A negatív kampány különböző értékelői abban többnyire egyetértenek, hogy a negatív kampány elsősorban a félelem érzését mozgósítja. A magyarországi esetben ez az említett módon az egyik oldalról a „kommunizmus" visszatértétől, a másik esetben a diktatúrától való félelem fenyegetését jelentette a két oldal támogatói számára. A pártok hívei mindinkább „véleménygettókba” zárták magukat, amelyekben a másik oldal megértése, érveinek elfogulatlan mérlegelése, ${ }^{27}$ sőt, egyáltalán a párbeszéd is egyre lehetetlenebbé vált:28 egyre nőtt a másik oldallal szembeni bizalmatlanság és félelem. Ezt a félelmet a negatív kampányok mértéktelenül igyekeztek felerősíteni. A baloldali pártok a centralizáló intézkedések „meghosszabbításával” egy totális egyszemélyi diktatúra rémképét vizionálták, és attól sem riadtak vissza, hogy ezt összekapcsolják a „fasizmus” fenyegetésével, mintha a jelenlegi kormánykoalíció uralma a náci Németország felé vezetne. Ez a kép nyilvánvalóan távol esik a valóságtól, de a negatív kampányban felkorbácsolt érzelmek és indulatok jegyében a támogatók egy jelentős része hagyta eluralkodni magán ezeket a - nagyrészt irracionális - félelmeket, és hasonló módon vállalta fel a szenvedélyes gyűlölet érzését a kormánypárt és annak vezetője ellen. ${ }^{29} \mathrm{~A}$ másik oldal belement ebbe a diskurzusba, és az MSZP (valamint a belőle kivált többi „baloldali” párt) ebben a verzióban nem egyszerűen az államszocializmus örököseként jelent meg: a hozzájuk kapcsolt képzetek a kommunista diktatúra legvéresebb éveit, az ötvenes éveket idézték, (amellyel már a későkádári vezetés sem vállalt azonosságot), összekapcsolva a friss emlékekkel: a 2006-os október 23-i eseményekkel, az akkori demonstráció véres szétverésével. A 2010 előtti kormányzásra való utalás más félelmek felerősitésére is alkalmas volt: a „baloldal” győzelmétől való félelmet a megszorító intézkedések visszatértének fenyegetésével is fel lehetett erősíteni. A negatív kampány másik összetevője a kormányoldal részéről a „baloldaliként” számon tartott pártok (MSZP, DK, Együtt) kriminalizálása volt: a korrupciós ügyek, választási csalások sokaságának felvonultatása, és az ezekbe belekeveredett személyek összekapcsolása a baloldali pártok vezetőivel. A korrupciós vádakat a „baloldali” vezetők cáfolni nem tudták, a montázshatást pedig hatékonyan használta ki a kormányoldal, a búnügyekbe keveredett személyek epitheton ornansaként sulykolva, hogy ők a baloldali pártvezetők helyettesei, bizalmasai, párttársai voltak, egyes vezetőket pedig személyükben is kapcsolatba hoztak ezekkel a búnügyekkel ${ }^{30}$. A „, baloldali pártok” is megpróbálkoztak korrupciós vádakkal, ezeket azonban a nyilvánosságban kevésbé tudták alátámasztani, mint ellenfelei a maguk vádjait, így ezek az ügyek nem is váltak a kampány részeivé. Mind a „jobb”, mind a „baloldal” egyébként úgy használta a különböző dokumentumhamisítási, szavazatvásárlási és egyéb ügyeket, mintha állandóan egymás (relatíve sikeresnek bizonyult) akcióit próbálnák lemásolni. ${ }^{31}$

27 „Az önigazolás, a szépítő hazugság illetve a gyülöletbeszéd két alrendszere egymást tartja fenn, a nyelvi kultúrharc fegyverzeteként" (Király 2010, 1/2: 33)

28 A miniszterelnök-jelöltek közötti vitát az utóbbi két kampányban már nem lehetett megtartani.

29 Az indulatkorbácsolás a legélesebben a kampánygyúléseken volt megfigyelhető.

30 A „gyanús ügyek” érzékeltetését azzal a szimbolikus képzettel is alátámasztották, hogy több plakáton is úgy ábrázolták az ellenzéki pártok vezetőit, mint akik egymás fülébe súgnak valamit.

31 Maga az, ahogy az ellenzék a kormányváltást „korszakváltásként” próbálta bemutatni, ahogy az „éhségmenettel” és néhány más alkalommal is megpróbálkozott a társadalmi felháborodás „utcára vitelével”, egyértelműen azon sikeres akciósorozat utánzási kísérletének tûnt, amellyel a Fidesz, (mint akkori ellenzék) az őszödi beszéd elleni tüntetések, a népszavazás kikényszerítésén és megnyerésén át eljutott 2010-ben a kétharmados többség megszerzéséig. Bár többnyire ezen akciók nem váltak a közvélemény többségét megnyerő „,közüggyé”, az időnként viszonylag nagyszámban összegyúlő tömegek által demonstrált erő (amit egyébként ilyenkor a kormányoldalnak mindig sikerült a Békemenettel túllicitálnia), láthatólag az ellenzék egyes vezetőit is 
A kölcsönös, gyűlöletté fokozódó ellenségesség a kampányok hangnemét is egyre durvábbá tette. Az egyik oldalról a „diktátor, fasiszta”, a másikról a „bűnszövetkezet” hangoztatása; a „baloldali pártok” már 2013ban készült kampányanyagaikban olyan kifejezéseket használtak a kormányoldal jellemzésére, mint: „tolvaj, vacak, hazug, terror, diktatúra, önkényuralom, éhbér”, a külföldön munkát kereső =„külföldre úzött”, sőt, olyan mondatok is bekerültek, hogy „a gyerekeket elveszik szüleiktől”. Az érzelem- és indulatkeltés eszközei között a vizuális kampányeszközökben még az - antiszemitizmusra utaló - majdnem küszöbalatti montázs alkalmazására is sor került. Említettük korábban a „maffiiakormány” kifejezést is. A különböző kampányanyagokban szerepel még az „ahogy a Fidesz bankot rabolt” kifejezés, a „lerombolták a jogállamot” (bilincsbevert kézzel illusztrálva). A kormányoldal a „búnszövetkezet-pártok”, a különböző, a „,baloldali pártok” tagjaihoz, támogatóihoz köthető bűncselekmények és a 2006-os rendőrterror emlegetése mellett ellenfeleit állandóan „bukott baloldalként” emlegette, egyszerre építve a „bukott” szónak az erkölcstelenséghez kapcsolt jelentéstartalmaira (lásd „bukott nő"), és arra, hogy az itt kormányváltó igénnyel fellépők már egyszer vereséget szenvedtek, megbuktak (s a sugallat szerint véglegesen, örökre megbuktak) ${ }^{32}$. A szociális indulatokat is mind a két oldal megpróbálta mozgósítani, a kormánypártiak a baloldali vezetők millióit-milliárdjait, vagyonosodását emlegetve; a baloldali koalíció pedig „a Fidesz mögötti oligarchák”33 kifejezést igyekezett „állandó jelzőként” besulykolni a köztudatba.

Az adok-kapok keretében a karaktergyilkosság ${ }^{34}$ számos esetével lehetett találkozni. Az ellenzék már a kormányzati ciklus elején ezzel az eszközzel „lőtte ki” az akkori köztársasági elnököt, Schmitt Pált. A másik oldalon a különböző bűnügyek, korrupciós ügyek a karaktergyilkosság még hatékonyabb eszközének bizonyultak. Bajnai Gordont és Gyurcsány Ferencet ugyan csak megérintette ezek szele ${ }^{35}$; Hagyó Miklós, Simon Gábor és mások perei, búnügyi, rendőrségi eljárásai nem csak az ő személyükre (és pártjukra) hatottak ki: a montázshatással a baloldali koalíció bármelyik vezetője hozzájuk volt kapcsolható. A kormányoldal kampányát segítették

abba a hitbe ringatta, hogy nekik is sikerülhet ezen a módon, a „közfelháborodás” hullámán felemelkedni. Ennek a makacsul ismételgetett elképzelésnek egyik utolsó megnyilvánulása volt a választások után a DK vezetőjének azon reakciója, amellyel mintegy „megfenyegette” a kormánykoalíciót: 2014 és 2018 között nem fogják kitölteni a 4 évet. A mindenkori ellenzéket tápláló proteszt-energiákat (a Góliáttal szemben mindig Dávid oldalán álló rokonszenvet) a Fidesznek kormányon is sikerült maga mögött tartania, azzal a következetesen alkalmazott szimbólumhasználati (és persze politikai) stratégiával, hogy tevékenysége középpontjába állította az EU-bürokráciával, a bankokkal és egyes multikkal szembeni ellenállás „szabadságharcát”.

32 A kormányoldalon álló CÖF egy propagandafüzetet adott ki „A Gyurcsány koalíció 7 főbűne” címmel, amelyen a baloldali koalíció vezetői és a már bírósági eljárás alatt álló Hagyó Miklós szerepelnek a plakáton is alkalmazott priuszfotó formában és a „Nem érdemelnek több esélyt, volt 8 évük"- 1-1 búnhöz társítva. Búnként a különböző megszorító intézkedések és a korrupció szerepelnek, de a „7 főbún” kifejezéssel az egyszerű erkölcsi elmarasztalás vallási képzetkört kap: a politikai ellenfelet ezzel mintegy a Sátán táborába utalva. A baloldali koalíció e füzet tükörképeként „A FIDESZ igazi arca” címmel adott ki propagandafüzetet (amely maszkban ábrázolja a miniszterelnököt). A füzet sorra védekezik a CÖF programfüzet vádjai ellen, de úgy, hogy ugyane témákban a kormánypártot vádolja: „azt hazudja a Fidesz és a CÖF” és „ezzel szemben tény”; illetve "arról viszont hallgatnak” szerkezetben. Mindkét oldal a negatívumokat a másik párt színeivel festi alá... A DK propagandafüzete szintén Orbán „búneit” sorolja (fekete alapon, szembeállítva a saját ígéretek világos oldalaival).

33 Az utánzás ebben is érezhető: annak tükörképe, ahogyan az akkori ellenzék a baloldali kormányok alatt például a „zöldbárók” emlegetésével próbálta a hatalom feudális jellegét hangsúlyozni.

34 A „karaktergyilkosság” során az ellenfél képviselőjét valamely, a közvélemény által is negatívan megítélt cselekményben bűnösnek találják, a tényeket, ha kell, felnagyítják, (tekintélyesebb személyek reputációjának rombolására bevetve olykor a gúny, a nevetségessé tétel eszközeit is), s ami a legfontosabb, mindaddig napirenden tartják, sulykolják, amíg a megcélzott személyt nem sikerül kiszorítani a politikai játéktérből, illetve, ha a támadás fő célja az illető pártja, akkor addig, amíg azzal gyengíteni lehet az adott pártot.

35 Bár Bajnai Gordon szereplésének végegyenlegében azért bizonyára benne van a „libaügy” hatása is. 
a média egyes csatornái is, amennyiben az ellenzéki politikusokkal folytatott beszélgetések nagy részét a kormányoldal kampányában felvetett tematizációhoz igazították.

Természetesen szélsőséges hangnemet használó pártküzdelmek majd minden parlamenti demokráciában előfordulnak. Ezek állandósulása és az indulatok eszkalálódása azonban semmiképpen sem nevezhető politikailag kívánatos állapotnak. Bár a gyűlöletbeszédet a másik oldalán mindkét fél elutasítja, és talán érzékelik azt is, hogy a társadalom többség számára az állandó ütközések, a társadalom éles politikai-ideológiai-kulturális megosztottsága nem kívánatos, a 2014-es kampányban nemigen voltak tapasztalhatóak a megosztottság csökkentésére, tompítására irányuló kezdeményezések ${ }^{36}$; a jelentős mértékú közeledést egyik fél sem teszi meg, attól tartva, hogy ez saját gyengesége kinyilvánítását jelentené.

A parlamentáris demokrácia azon alapszik, hogy a társadalom vertikális rendi tagozódását a polgári társadalmak ideológiai megosztottsággal helyettesítették (ezt fejezte ki már az első évszázadokban a rendek közti harc whigek és toryk pártküzdelmévé változtatása; ezt fejezte ki a francia Nemzetgyúlésből származó felosztás „jobb-” és „baloldali” pártok között). Ebben a társadalmi rendszerben az ideológiai megosztottságon keresztül fejeződnek ki a domináns csoportok érdekellentétei, és - hogy megőrizzék felettük hegemóniájukat - ebbe csatornázzák be az alávetett csoportok érdekeinek megszólaltatását is. Ennek a rendszernek alapérdeke, hogy ilyen ideológiai megosztottságok tagolják a társadalmat, állítsák szembe egymással annak csoportjait. Ugyanakkor a politikai mezőt jobb-, és baloldalra osztó testmetaforának van egy másik oldala is. A testben a bal és jobb együtt alkotják az egészet, egymásra vannak utalva. Amikor jól múködik a parlamentáris demokrácia, akkor az „oldalak” pontosan tudják, hogy a másik oldalra, annak értékeire is szükség van, és így - a kölcsönös tisztelet jegyében-- is viszonyulnak egymáshoz. Amikor a pártok közötti nagyrészt amúgyis mesterséges ideológiai különbségeket oly mértékben felfokozzák, hogy a nézetek versengése és diskurzusa gyűlöletté válik, az a demokrácia szempontjából is vészjelzés. A bizalmatlanság (ami a párthívekben a másik oldallal szembeni bizalmatlanság) a társadalomban a politika iránti általános bizalmatlansággá növekszik; (ezt csak fokozza az, hogy a kölcsönös negatív kampányok során - mint erre már utaltunk -, mindkét oldalra: - tehát az egész politikai elitre - elég sok árnyék vetül). Ez megerősítheti új, politikai erők esélyeit, de ha azok is bekeverednek az adokkapokba, akkor egy idő múlva maga a parlamenti politizálás veszítheti el a legitimációját. Ha egy társadalomban túl erősen előtérbe kerül a korrupció, a hazugság, a tisztességtelen politikai eszközök használata, ez nem csak az ellenfélre vetül rá, akivel szemben e vádak megfogalmaztatnak. Amikor úgy tűnhet, hogy mindez széles körben eluralkodott, a közvélemény, főleg, ha úgy véli, hogy a politikai szféra, mint olyan eltávolodott tőle, a különböző politikai aktorokat hajlamos egy halmazba, a „politikusok”, a „politikai elit” halmazába sorolni, s így a korrup-

36 Erős, közvetítő jellegű centrumpártok nincsenek: a „centrum” szerepét a mindenkori kormánypártok (tehát a két fő oldal képviselői) maguk próbálják elfoglalni. (Ez a Fidesznek, amelynek egyaránt van - és mindig is volt-- „baloldali” és „jobboldali” ellenzéke, sokkal jobban sikerült, mint az MSZP-nek, hiszen a politikai mezőben számba jöhető radikális baloldali-- sőt, sokak szerint igazi baloldali-- párt egyáltalán nincsen). „Harmadik erő” nem mindig a centrumban jön létre. A kétpólusú megosztottság elleni közérzületet ezúttal paradox módon annak a Jobbiknak sikerült kampányával leginkább kihasználnia, amelyet korábban éppen a szélsőséges indulatok megjelenítőjeként tartottak számon. A Jobbik ezúttal, (mint erről már szó volt) - a radikális hangot megtartva tömeggyúléseik keretei között - a nyugodt érvelés, a pozitív kampány, a mosolyos fiatalosság stílusát választotta, szembeállítva azt a nagy pártok kölcsönös ellenségeskedésével. (Ezzel a kisebb pártok is megpróbálkoztak - lásd például az FKGP „mi nem a sárdobálásból élünk” jelszavát - de ahhoz, hogy egy pártot „harmadik erőként” fogadjanak el, valóban erő, tömegtámogatás is szükséges). 
ció, a hazugság, a tisztességtelen eszközök használatának gyanúja nemcsak az ezekkel megvádolt ellenfelekre, hanem valamennyi számottevő pártra rásugározhat. Hiszen a pártok egymás támadásaihoz való politikai igazodása, a másik oldalán sikeresnek bizonyult eszközök kopírozó átvétele is erősíti azt a véleményt, hogy „egyik kutya, másik eb". Arról nem is beszélve, amikor a másik által alkalmazott eszközök hatékonyságára hivatkozva olyan módszereket vesznek át, amelyek tisztessége megkérdőjelezhető: a valóságos és tartós felülkerekedést csak erkölcsi fölény megőrzésével, s a „ne kívánd felebarátodnak azt, amit magadnak nem kívánsz” következetes alkalmazásával lehet elérni37.

Az egymás elleni indulatok a pártok támogatói (és ellendrukkerei) körében a legszélsőségesebb formában talán a plakátfirkálásokban jelentkeznek. 1998-as elemzésünkben a plakátfirkálások különböző motivációkat tükröző típusait különböztettük meg: a) a „rábeszélőgép” elleni védekezés vicc, humor formájában; b) az egyoldalú kommunikáció kétoldalúvá tétele; c) street art, graffiti (kreativitás); d) politikai intolerancia kifejeződése (az arc tönkretétele, az ember-mivolt megsemmisítése, dehonesztáló megbélyegzés). Azóta az átfirkálások többsége sajnálatos módon a „d” típus, a politikai intolerancia kifejeződésének irányába tolódott el.

A pártok közötti ellenségeskedés légkörében a pártok táboraiban jó talajra találnak az összeesküvés-elméletek is. Ez tovább rombolhatja a társadalom kohézióját, hiszen a szembenállás erőit és motívumait még a valóságosnál is sokkal szélsőségesebbnek mutatja. A pártok küzdelme ilyenkor, ahelyett, hogy a többpártrendszer eredeti funkciója szerint segítene a különböző értékek integrálásában, abban, hogy a különböző csoportok és egyének megtalálják helyüket a társadalomban, távolítja egymástól a társadalmat és annak alkotóelemeit. Talán érdemes itt utalni az összeesküvés-elméletek jelenségköréről a 2010-es kampány kapcsán írottakra (Kapitány-Kapitány 2010: 259-265).

\section{Integráló hatású kampányeszközök}

Ha azt állítottuk, hogy a negatív összkép sugallata maga is dezintegráló hatású, mi sem állhatunk meg a negatív jelenségek sorolásánál. Észre kell vennünk a kampányban az integráció szempontjából - legalább potenciálisan - pozitívumnak minősíthető, bár közvetlenül nem feltétlenül integratív céllal alkalmazott elemeket is.

Ilyen elemnek számít, amikor a pártok kampánya a választópolgárok közös élményeire próbál építeni, hiszen a közös élmények összeköttetést hoznak létre az emberek között ${ }^{38}$. A különböző pártok különböző módon (hol feltételezett alapérzelmekre, ezeket felidéző hangulatokra, hol ismerős környezetekre, hol a médiának a világot bemutató megszokott vizuális hatóeszközeire stb. építve) próbálják a közös élményeket mozgósítani, s

37 Mint már említettük, az eldurvult ellenségeskedés légkörében általános a kettős mérce alkalmazása; erkölcsi fölényre csak az tehet szert a másikkal szemben, aki önmagával, a saját politikai oldalával szemben ugyanazokat a megítélési kritériumokat alkalmazza, amelyek alapján a másik magatartását elutasítja. A kettős mérce kerülése a jelenlegi politikai életben sajnálatosan fehér hollónak számít.

38 A más nemzetbeliekkel kötött házasságok előtt álló egyik leggyakoribb nehézség is éppen a közös gyerekkori élmények hiánya. A globalizáció korában az is elősegíti a különböző nemzetekből származó felek közötti házasságokat, hogy a közös élmények aránya növekszik: a világ különböző pontjain felnövekvők ugyanazokon a filmeken, tévésorozatokon, sporteseményeken nőnek fel, ugyanazok a világpolitikai események formálják a politikai tudatukat, ugyanazokat a zenéket hallgatják, ugyanazokat a számítógépes játékokat játsszák, stb. A közös élmény viszont összekötő lehet nemcsak egyének, de a különböző politikai kultúrák „együttélésében” is. 
ezzel hatni a választók azonosulási képességére. ${ }^{39}$

A közös élményeknél is erősebb integráló tényező, ha a különböző politikai táborokat elválasztó „lövészárkok” fölött közös értékek ívelnek át. Mindig nagyon fontos (lenne) az a kérdés, hogy a különböző „oldalak” között van-e (a meghatározó értékekre is vonatkozó) érintkezési felület? Vannak-e olyan szimbólumok, amelyek a pártokon kormány/ellenzék megoszlásokon átívelő integráló erővel bírnak? ${ }^{40} \mathrm{~A}$ nemzetállam, mint magasabb integráló egység szempontjából mindig ilyenek a nemzeti szimbólumok. Ezek elvben minden politikai résztvevő számára közös értéket képviselnek. A gyakorlatban azonban egyrészt világos, hogy (1) a különböző politikai szubkultúrák eleve különböző mértékben identifikálódnak ezekkel a szimbólumokkal; másrészt (2) a különböző történelmi helyzetekben e szimbólumoknak objektíve is változik identifikáló, közösséghez tartozást kifejező ereje: olykor kiüresednek, inflálódnak vagy éppen korrumpálódnak, máskor felerősödnek, eleven érzelmekkel telítődnek. Harmadrészt (3) kiélesedő versenyhelyzetben a versenytársaktól való elkülönülés érdekében egyes politikai csoportok saját „nemzeti szimbólumokat” választanak le a közös szimbólumokról. Nemzeti szimbólumokról - e szempontból is - két értelemben beszélhetünk. Szúkebb értelemben vett nemzeti szimbólumok: a címer, a zászló, (és általában a nemzeti színek), a Himnusz, a Parlament, az országtérkép. Magyarországon még: a Szózat, a Nemzeti dal, operaáriák, mint a Hazám, hazám...; egyes popdalok, mint az István király, a Máté Péter féle Hazám stb., a nemzeti ünnepek: március 15., augusztus 20. és október 23. Ezek többé-kevésbé mindenki számára a saját nemzet szimbólumaiként jelennek meg (bár a popdalok esetében nyilván nemzedéki felső határokkal). A kiüresedés és az elkülönülési szándékok következtében e szimbólumok egyike-másika helyett (vagy inkább: mellett, de külön hangsúllyal) további identifikációs és közösségjelző szimbólumokat kezdenek alkalmazni. Így jelennek meg a nagyobb nemzeti elkötelezettség jelzésének szándékával az országtérkép mellett-helyett a Nagy-Magyarország térképek, a nemzeti trikolór mellett-helyett az Árpádsávos zászlók; a Himnusz és a Szózat mellett a Székely himnusz és a Boldogasszony anyánk; a történelmi viseletek. Ezek azonban magától értetődően már nem minden csoport számára testesítik meg a nemzeti összetartozást, s ezért integráló hatást is csak az ezekkel eleve azonosulókra gyakorolnak. A tágabb értelemben vett nemzeti szimbólum mindaz, amit a magyarságra jellemzőnek vélhetünk. Mivel ezek nagy részét nem kanonizálták az elmúlt évszázadokban a szűk értelemben vett szimbólumokhoz hasonló módon, ezért nyilván nem is teremtenek teljes közösséget a nemzet tagjai között (a hozzájuk való viszonyban sokkal több a szubjektív mozzanat, és a szubkulturális megoszlás) (részletesebben: Kapitány-Kapitány 2002); ugyanakkor - éppen a kanonizálás hiánya miatt közvetlenebbül kapcsolódnak az emberek mindennapi (és a politikai megosztottságtól kevésbé érintetten közös) életvilágához, s ezért a politikai-megosztó dezintegratív tendenciák is kevésbé érintik őket. ${ }^{41}$

39 A közös élményekre alapozás a kereskedelmi reklámoknak is fontos hatóeszköze (a termékkel való azonosulás kiváltására). A kereskedelmi reklámok esetében is ambivalens azonban a hatás. A túlságosan ismerős unalmassá válhat, a túlságosan egy értéket sugalló reklám pedig nem hat azokra, akik nem azt az értéket preferálják. A közös élményre építő kampányfilmek is ezért olykor kombinálják az ismerőst az újszerúvel (mint az LMP említett reklámfilmjében), vagy a domináns érték mellett helyt adnak más értékeknek is.

40 A szimbólumoknak mindig vannak identitáskifejező, közösséghez tartozást jelző funkciói, s ezért ha egyes szimbólumok közösek tudnak lenni a különböző szubkultúrákban, ez magában hordja annak az esélyét, hogy az egyes (politikai) szubkultúrákat integráló magasabb közösség-egység is létrejöjjön. (A szimbólumok ezen funkciójáról lásd pl. Firth 1973, Kapitány-Kapitány 2008.

41 Hogy a gólya, a puli vagy a ló; a tulipán, a rózsa vagy a paprika; a Duna, a Tisza, vagy a Balaton; az Egri csillagok, a néptánc vagy a Rubik kocka (és a megannyi „hungarikum”), kinek mennyire nemzeti szimbólum, ez számos szubjektív mozzanat függvénye, de ezekhez az irodalom, a történelem, a képzőmúvészetek, a zenei kultúra által közvetített, az iskolai oktatásban, médiában, a 
A politikai megosztottságok fölötti közös nevezőket teremthet a vallás közössége is. Szó volt már arról, hogy az egyház integrációs törekvése kezdettől fogva alterált a nemzetállami integrációval, de a két integrációs erő hamar megtalálta az együttes hatás lehetőségét is. Vannak történelmi korszakok, amikor ezek egymást erősítő integrációs hatások. Akár az államvallások esetére gondolunk, akár arra, amikor az egyház az idegen hatalmak általi alávetettségben áll az ellenálló nemzet mellé, mint például a szocializmus idején különösen Lengyelországban. Máskor - az egyházak üldözése, a nemzetállam által támogatott szekularizáció korszakaiban - e kétféle integrációs erő ütközik. Markáns példáját adják ennek azok az iszlám államok, ahol a vallási fundamentalizmus és a nacionalista hadseregek erői állnak a két oldalon. Egyház sosem lehet maradéktalanul a nemzeti integráció fó ereje több vallású, több egyházú országokban (mint amilyen Magyarország is); Magyarországon ehelyett a „kereszténység” (mint egy egész kultúrkört összefogó) eszmény igyekszik betölteni ezt a szerepet, közös nevezőt kínálva valamennyi keresztény felekezet tagjai számára. Ebből az integrációs mezőből azért óhatatlanul kimaradnak a nem-keresztény felekezetek hívei és az elkötelezett ateisták, de ezt a közös alapot például - elődpártjaik egyház- és vallásüldöző tevékenységét feledtetendő - a különböző szocialista pártok is többé-kevésbé elfogadják.

Mind a nemzeti, mind a vallási szimbolika elvben a nemzetállam integrációját segítő tényező lehet, és a kampányokban is ekként jelennek meg, de mivel a közös nevezőnél ma Magyarországon erősebbek a megosztó hatások, mindkét képzetkörhöz kirekesztő asszociációk is társulhatnak. Egyrészt mert egyes politikai aktorok eleve ilyen szándékkal, de legalábbis a megkülönböztetés-elhatárolás szándékával használják ezeket a szimbólumokat; másrészt azokra a csoportokra, akik ezekkel a szimbólumokkal nem tudnak azonosulni e szimbólumok természetesen nem gyakorolnak integrativ hatást, sőt, e csoportok tagjai e szimbolikára olykor - a kiélesedett ellentétek folytán - túlérzékenységgel, a semleges mozzanatokban is kirekesztést feltételezve reagálnak.

A harmadik nagy integrációs egységnek, az EU-nak is megvan a maga szimbolikája. Ennek elemei (a szúkebb értelemben vett szimbólumok között a zászló, a csillagok) korántsem bírnak a nemzeti és vallási szimbólumokéval összehasonlítható erővel, de a kampányokban - hiszen a magyar politikai mező ez idő szerint része az európai politikai mezőnek - használják e szimbólumokat is. A leghangsúlyosabban nyilvánvalóan azok a pártok, amelyek egyrészt támogatják az EU-integrációt, másrészt hazai támogatottságukat nagyobb fokú EUtámogatással próbálják megerősíteni. Ez leginkább a DK-t és talán még markánsabban az Együtt-PM-t jelenti, mely utóbbi az EU-választási kampányt a nemzeti és az EU-zászló hangsúlyozottan egyenrangú alkalmazásával - a futballrajongók felfokozott identitásjelző megoldásával, a két arcfélre festve-matricázva - vitték végig.

Integráló erőként használják a kampányokban a nemzetnél, egyháznál, EU-nál is átfogóbb közös-séget megtestesítő értékeket, hiszen az emberiség egészében többé-kevésbé közösnek mondhatóak a biztonság, a jólét, az egészség, az otthon, a szeretet-együttmúködés, stb. értékei. A politikai verseny szempontjából ezekkel kapcsolatban (is) nyilván az a kulcskérdés, hogy melyik pártnak sikerül ezeket az értékeket a viszonylag leghitelesebben önmagához társítania; integrációs szempontból azonban az ilyen értékek használata mindenképpen pozitiv. Még ha tudják is a választók, hogy egy adott párt hipokrita módon hivatkozik mondjuk a szeretet érté-

mindennapi tapasztalatokban ismétlődő motívumokhoz valamilyen mértékben az emberek túlnyomó része számára (nemzeti) érzelmek kapcsolódnak, s ezen érzelmek kiváltása, ha más módon is, de ugyanúgy integratív hatással járhat, mint a mindenki által elfogadott szúkebb értelemben vett nemzeti szimbólumok (lásd erről: Kapitány-Kapitány 2002). 
kére, (mert a politikai versenyben nem éppen szeretetteljesen viselkedik ellenfeleivel szemben), vagy hogy gazdaságpolitikája nem büszkélkedhet jelentős sikerekkel a jólét vagy a biztonság megteremtésében ${ }^{42}$, maguknak ezeknek a pozitív, építő jellegű értékeknek a hangsúlyozása (például a nyílt gyűlöletszítással szemben) erősíti a közös nevezőt azok között az emberek között, akik számára ezek az értékek fontosak, tehát mindenképpen integratív hatású. Röviden itt arról van szó, hogy az olyan tematizáció (s ez nem csak az említettekhez hasonló célértékekre, hanem például egyes, mindenkit foglalkoztató problémák megfogalmazására is érvényes), amely a legkülönfélébb csoportok számára egyaránt fontos, önmagában is integratív erejú. Ha az emberek között nincs is egyetértés például a problémák megoldási irányára vonatkozóan, de a diskurzus ténye, a téma közös elfogadása, fontosnak tekintése maga is növelheti az integrációt. Amikor fentebb azt hangsúlyoztuk, hogy a modern demokráciákban maga a politikai rendszer integrativ, lényegében ugyanerről volt szó: a modern politikai demokrácia elvben éppen azt a lehetőséget teremti meg, hogy a társadalom számára fontos problémákat - a résztvevők túlnyomó többsége számára legitim módon, tehát például a demokratikus intézményrendszer keretei között illetve a szabad nyilvánosságban - megvitassák; s ezáltal maga a megvitatás, s az ennek kereteit biztosító intézmények és nyilvánosságformák az integráció forrásai³ . A tematika közössége olykor "motívumvándorlást” hozhat létre az egyes pártok kampányanyagai között, s ilyen „vándorlás” az alkalmazott módszerek tekintetében is kimutatható, amikor - mint erre más vonatkozásban már utaltunk - egyes pártok versenytársaik egyes sikeresnek bizonyult akcióinak lekopírozásával próbálkoznak. (Ezzel kapcsolatban megint elmondható, hogy az ilyen megoldások többszörös, nem-feltétlenül kívánt következménnyel járhatnak. Egyrészt önállótlannak mutatják a csak a másik utánzására képes politikai erőt, másrészt e gyakorlat gyakran a kettős mérce alkalmazásához vezet - elítélem amit a másik csinál, de aztán én is ugyanazt teszem. Harmadrészt mivel nincs két egyforma szituáció, ami az egyik esetben sikeres, egyáltalán nem biztos, hogy a másik esetben is alkalmazható44. Integrációs szempontból viszont ez esetben is egy paradox hatás jöhet létre: egyfelől az egész politikai elittel szembeni bizalmat gyengítheti az „egyik kutya, másik eb” tapasztalata, a pártok közti hasonlóság érzetének fokozódása, és ez össztársadalmi szempontból dezintegrativ; ugyanakkor - ez jól látható például azokban a rendszerekben, ahol két nagy, és az alapkérdésekben egymáshoz nagyon hasonlóan viselkedő váltópárt kormányoz felváltva - a tematika és a módszerek közössége legalább annyira integratív hatású is, amennyiben azt sugallja, hogy az illető társadalom számára adott politikai mező (ha nem is a legvonzóbban, de) egységesen múködő rendszer5.

42 Ha például jelentős csoportok számára nem igazolódnak is vissza egy politikai erő azon ígéretei, miszerint az adott politikai szereplő a jólét emelője lenne, mert ők éppen a jólét hiányát tapasztalják, a jólét mint célérték ettől csak még fontosabb lesz a számukra, s ez ha az adott, hiteltelennek tapasztalt politikai erő támogatottságát nem növeli is, integrációs hatást - a közös értéknek a figyelem fókuszában tartásával - mégis kifejt. Ugyanez az összes, az emberek túlnyomó része számára fontos, pozitiv értéktételezésről elmondható.

43 „Le kell szögezni mindjárt az elején, hogy a politika lételeme a konfliktus, az ellentét. Ebben az értelemben a politika maga is hoz létre dezintegrációs folyamatokat, nem pedig pusztán visszatükröz vagy képvisel mélyben megbúvó gazdasági, szociális, identitásbeli, kulturális, vallási stb. ellentéteket. (...) Konfliktusok azonban nemcsak negatívak lehetnek, hanem pozitivak is. Könnyü belátni, hogy amíg van vita, van veszekedés, addig még értékkel bír a kapcsolat, a közösség fenntartása; ebben az értelemben a vita nem dezintegrációs, hanem inkább integrációs mechanizmus (...) a mai ideológia láthatatlan, mert csak annyit állít, hogy maga a kommunikáció integrál, függetlenül a tartalmától. A kommunikáció jó része egyet nem értés, éppen nem konszenzus, ám az ideológia szerint nem szükséges a konszenzus ahhoz, hogy a társadalom egyben maradjon, az is elegendö, ha fennáll a kommunikáció". (Kiss B. 2015 - jelen számban).

44 Hatékonyabbnak az olyan megoldások bizonyulnak, amikor az ellenfél sikeres módszereit úgy veszik át, s kombinálják más elemekkel, hogy az már „valami egészen másnak” túnik.

45 A társadalom bármely összetevőjének konzekvens, rendszerszerű múködése nagy integratív erő. Ebből a szempontból - ha konzek- 
Longitudinális vizsgálatunk során korábban leírtunk (Kapitány-Kapitány 1998) egy olyan tendenciát, miszerint - bár közvetlen összefüggés a kampányok és a választási eredmények között nem mutatható ki -- a választásokon többnyire az olyan pártok győznek, amelyek a pártok összessége által leggyakrabban említett értékek közül a legtöbbet tudják beépíteni kampányanyagaikba. „Vagyis minden választásnak van egy általános - a pártok által feltételezett közvéleményhez igazodó - értékdivatja, s az esélyes pártok általában azok, akik többet használnak e 'divat' által leginkább preferált értékek közül, (hozzátéve, hogy a későbbi győztesek sok ilyen értéket használnak, 'rajta tartják kezüket a kor ütőerén', attól viszont, hogy egy párt nagyon sok ilyen értéket használ, még nem lesz győztes.") (Kapitány-Kapitány 1998:26). Ez a tendencia is arra utal, hogy a pártok versenyének egyik legfőbb tétje az, hogy ki tudja legsikeresebben integrálni a választóközönséget (annak minél nagyobb részét), például azáltal, hogy a leginkább „levegőben lévő” tematikát, értékeket szólaltatja meg. Itt azonban felmerülhet a kérdés: valóban arról van szó, hogy a pártok a „legsikeresebb integráló” pozíciójának megszerzése érdekében a „közvéleményhez”, az emberek számára legfontosabb kérdésekhez, értékekhez és problémákhoz igazodnak? Vagy az említett összefüggés csupán annak köszönhető, hogy a politikai elit egésze időnként bizonyos témákat sulykol, bizonyos értékeket fókuszba helyez, s ezeket kínálja fel integráló közös nevezőnek - mintegy felülről - a társadalom számára? A legvalószínúbb, hogy mindkettőről szó van: a közvéleményben felszínre kerülő problémák és értékek hatnak a pártok tematizáló tevékenységére, a pártok pedig megpróbálnak a politikai elit által szolgált érdekek szerint tematizálni és értékpreferenciákat kijelölni, s ezzel befolyásolják, terelik a közvéleményt. S persze van az értékeknek és problémafelvetéseknek egy olyan önmozgása is, hogy bizonyos fejlemények hiányt teremtenek, felértékelik a sokáig háttérbe helyezett értékeket, nem-tematizált problémákat, s egy következő időszakban éppen ezek fognak előtérbe kerülni. A piaci társadalmakban a gazdaság - kereslet, kínálat és hiány viszonyában - ugyanígy múködik; a politikai rendszer múködése e tekintetben (is) leképezi a piacgazdaság szerkezetét. Hosszú távon nyilvánvalóan erősebb integrációt teremt a „keresleti piac”; ugyanis, ha a politikai mezőben túlságosan a kínálati oldal dominál (ami felé a gazdaság egyébként nagyon is eltolódott a 20. század folyamán), s nem az emberek számára legfontosabb problémák és értékek tematizálódnak, ez azokat, akiknek az értékrendje és életproblémái kimaradnak az integrációhoz a politikai elit által felkínált „,közös nevezőből”, az integrált társadalmi mezőtől létükben is távolítja.

Ezért az integráció szempontjából minden kampányban alapvető kérdés az, hogy az egyes pártok mely csoportokat szólítják meg. Ha olyan mozzanatok jelennek meg, amelytől egyes csoportok fenyegetve érzik magukat, ez mindenképpen dezintegratív hatású. De nagyon lényeges kérdés az is, hogy az integráció szempontjából sérülékenynek számító csoportok mennyire jelennek meg, helyzetük mennyire és hogyan tematizálódik. A munkanélküliek például - s itt olyan csoportról van szó, amelynek a munka világából kiszorulva a társadalmi lét egyik legfontosabb integráló mechanizmusát kell nélkülöznie - csak közvetve, (munkahely-ígéretekkel) váltak a 2014-es kampány részévé; jelen állapotuk javítása, az integrálásukra tett erőfeszítések nagyon kevéssé

vensen és az egész rendszert átfogóan múködik - például még korrupt rendszerek is lehetnek jól integráltak, amennyiben a korrupció játékszabályait mindenki megtanulja és alkalmazza, ez nagyobb integrációt biztosít, mint a kiszámíthatatlan rendszerek. Persze nem tekinthetünk el attól, hogy ha egy rendszer olyan destruktív integratív mechanizmusokra épül, mint amilyen a korrupció is, az integrációt rögtön gyengítheti is a rendszer alacsonyabb fokú hatékonysága, s ezáltal mindig megkérdőjelezhető ésszerúsége, és az hogy állandó ütközésben van a társadalom egy olyan lényeges és alapvető integrációs mechanizmusával, amit a társadalom többsége számára közös erkölcsi elvek és igazságossági kritériumok képviselnek. 
tematizálódtak. Egy másik (anyagilag is) sérülékeny helyzetben lévő csoport a nyugdíjasoké; ők valamivel több figyelmet kaptak (mind a kormányoldal, mind az ellenzéki koalíció hangsúlyosan megszólította őket, az egyik kisebb párt - a Szociáldemokraták - pedig kifejezetten az ő érdekképviseletükként definiálta magát). A mélyszegénységben élők és a cigányság az említés szintjén rendszeresen szerepelnek a politikai diskurzusokban, egyes programokban tervek is megjelennek velük kapcsolatban. Rájuk is érvényes azonban, ami a munkanélküliek kapcsán elmondható: valóságos, hatékony integrálásukra eddig kevés eredményes lépés történt, és ebben ez a kampány sem jelentett előrelépést. Ugyanez vonatkozik az üzemi munkásságnak (és a mezőgazdaságban alkalmazottaknak) azokra a még mindig eléggé széles csoportjaira is, amelyek a szocializmus rendszerében - ha olykor csak propagandaszinten is - sokkal nagyobb mértékben voltak a figyelem fókuszában, és a jelenleginél mindenképpen erősebb érdekérvényesítési pozícióikkal bírtak. A rendszerváltás óta viszont (s ez mindegyik kormányzati ciklusra és mindegyik kampányra vonatkozik), lényegében kiestek a külsődleges megjelenítéstől mélyebben „megszólítottak” köréből, s ez integrációjukat mindenképpen gyengíti, és rendre olyan „protesztszavazatokra" késztetheti őket, amelytől a jelenlegi integrációs mechanizmusok gyökeres megváltoztatását remélik.

Egy politikai erő számára igen kedvező, ha olyan, a nemzet-méretű integrációt növelő eseményekre tud hivatkozni, amelyekről azt is el tudja fogadtatni a közvéleménnyel, hogy ezen események valamilyen szinten az ő tevékenységükkel hozhatók összefüggésbe. A kormányoldal 2014-es sikerének egyik komponense nyilván az, hogy a „spirituális nemzetegyesítést”, a határon túli magyarsággal való kapcsolatok szorosabbra húzását leginkább hozzájuk lehetett társítani. Szempontjukból megerősítőnek bizonyult az is, hogy a legutóbbi árvíz elleni védekezés olyan többé-kevésbé sikeres eseménysorként csapódott le a közvélemény ítéletében, amely egy közös nemzeti cél érdekében időlegesen egyesítette a különböző politikai oldalak, szubkultúrák tagjait, s mivel ezen eseménysor az éppen záruló kormányzati ciklusban történt, a jelenlegi kormánypártokhoz volt kapcsolható. Az olyan kormányzati intézkedések, amelyek gyakorlatilag mindenkit, vagy majdnem mindenkit kedvezően érintenek, szintén integratív hatásúak. A kormányoldalnak a választási kampányban például különösen a rezsicsökkentést sikerült ilyen, az emberek többségének helyeslését kiváltó, s ezért őket e véleményben összefogó hatásként felhasználnia a választók jelentős részének megnyerésére.

A „közös” mozzanatot leginkább garantáló képzetkörök közé tartozik a jövő felidézése. A jövő mindenki közös jövője, aki megéri (s ki ne akarná megérni?) Ezért a (jobb, szebb, igazságosabb) jövő ígérete a történelem kezdetei óta az egyik legfőbb politikai csáberő. A különböző politikai erők versenyében az jut előnyhöz, akinek leginkább sikerül ezt a jövőt önmagához társítani. Ebben pedig komoly szerepe lehet az adott pártot támogatók korösszetételének: minél jellemzőbb egy pártra, hogy a fiatalok választják, annál jobb eséllyel jeleníti meg magát a „jövő" képviselőjeként ${ }^{46}$. Ez azonban önmagában nem elég. Bármely politikai szereplő „jövő víziója” akkor vált ki széles körben azonosulást, ha a társadalom nagy része feltételezheti azt, hogy ebbe a jövőbe ő is szervesen beépülhet, őt is integrálják.

Magától értetődő, hogy a radikális változtatás csak akkor és azok körében alkalmas jövő-vízió, akik a je-

46 A 2014-es kampányban a nagyobb pártok közül elsősorban a Jobbik és az LMP épített erre (a választási eredmények tanúsága szerint a Jobbiknak országosan ezzel sokkal szélesebb kört sikerült elérnie, míg az LMP a fővárosban tudott nagyobb választói csoportokat megszólítani). 
lennel alapvetően elégedetlenek, akik a jelen világában nem érzik magukat kellőképpen integráltnak. Akik így vagy úgy megtalálják helyüket a jelen társadalmi viszonyaiban, azok számára a megnyugtató jövő éppen hogy a folytonosságban van. Minden kormányzat - amíg nem játssza el a társadalmi többség bizalmát, amíg integrációs törekvései elérik a társadalom nagyobb részét - számíthat annak a régi szociálpszichológiai törvényszerűségnek az érvényesülésére is, amely az emberek nagy részét az adott hatalomhoz való igazodásra készteti, (ha ez a személyes érdekekkel összeegyeztethető). Ez a reflex nem marasztalható el pusztán „konformista alattvalói attitűdként": éppen ez az egyik olyan mechanizmus, amellyel a társadalom a dezintegráció ellen védekezik. Amíg nincs szélsőséges válság, a társadalom ily módon spontán „összezár": sok más tényező mellett ez teszi az olyan kormányzatokat, amelyek nem konfrontálódnak szélsőségesen a többség személyes érdekeivel, oly hosszan stabillá. Annak, hogy a többség ily módon elfogadja egy politikai erő integrációs kínálatát, vannak olyan szimbolikus összetevői is, mint az adott politikai pártot képviselő személyek imázsa: mennyire széles kör érezheti azt, hogy e személyek lényegében „olyanok, mint ő”. (Ami nem jelent egyebet, mint hogy az ő identitását meghatározó közösség egyes képviselői, lám, részt vesznek a hatalomban, s ezáltal vélhetően az ő integrálása is biztosítva van). Ebből a szempontból nem a hatalomban megjelenő személyek származása a döntő, még csak nem is az általuk képviselt programok, bár persze ezek sem lényegtelenek; hanem azok a magatartásformák és nyelvi stílusok, amitől a választó a hatalomban lévővel - lehetőleg minél több vonatkozásban - egyazon identitásközösség tagjának érezheti magát ${ }^{47}$.

\section{Az integrációs szintek néhány lehetséges konfliktusa}

A 2014-es kampány integráló szerepe szempontjából különös fontosságot kell azonban tulajdonítani annak a korábban többször is említett lehetőségnek, hogy a nemzeti szintú integráció és az európai integráció képviselete ellentétbe kerül. Már az EU-hoz való csatlakozás idején kiütköztek azok a nézőpont-különbségek, amelyek egyik oldalán a teljes integráció (sőt, egyes elképzelések szerint a teljes, hosszú távon a nyelvi-kulturális elkülönülést is feladó asszimiláció), a másik oldalán a nemzeti érdekek preferenciája állt. A csatlakozás idején a közvéleményben az EU-integráció olyan oldalai domináltak, mint a szabad utazás, munkavállalás, információáramlás, a határok ilyen értelemben vett spiritualizálódása, s ezek - tekintve az EU magországainak magasabb életszínvonalát, technikai, infrastrukturális fejlettségét is - egyértelműen az integráció „emelö” hatásait ígérték. Később azonban világossá váltak az unió egységesítésének több társadalom számára (s így a magyar társadalom számára is) hátrányos következményei (hátrányos gazdasági döntések, szabályozások, a kulturális diverzitás veszélybe kerülése, az EU-n belüli nem egyenrangú érdekérvényesítési lehetőségek) is. Ezek után a pártok közvélemény általi megítélésében eléggé kardinális kérdés lett, hogy egy-egy politikai erő az „Európai Egyesült Államok”, vagy a „Nemzetállamok Európája” koncepciója mellé áll-e, vagy éppen szembefordul az európai integrációval. Az európai és a nemzeti integrációs elv több vonatkozásban szembekerült egymással (emögött persze alapvető gazdasági kérdések húzódtak: a magyar gazdaság képes-e nemzetgazdaságként működni - ez esetben a nemzetgazdaság a legfőbb integráló erő; vagy csak az egységesülő európai gazdaság integráló szempontjai érvényesülnek, amelyekben a sajátos magyar érdekek óhatatlanul csak szerényebben

47 Aki például el akarja nyerni a vidéki többség támogatását, hiába áll ki a „vidék” érdekei mellett, s hiába bizonyítja vidéki származását is, ha azokban a metakommunikációs gesztusokban, és megfogalmazás-módokban, amelyek a „fővárosi” és „vidéki” identitások különbségeinek kifejeződései, nem bizonyul a „vidéki Magyarország” hiteles megtestesítőjének vagy legalábbis értőjének. 
vétetnek figyelembe). Természetesen e szembekerülés egyáltalán nem szükségszerú. Sőt, mint fentebb állítottuk, maga ez a szembekerülés dezintegráló hatású (mind az EU, mind a nemzetek szintjén); és Európa optimális integrációja is éppen akkor lehetséges, - itt újra hangsúlyoznunk kell, hogy nem politológiai, hanem, érték- és szimbólumszempontú elemzést végzünk - ha nem a nemzeti szintek érdekei ellenében történik, hanem azokkal összehangolva. Az érdekütközés egyébként alapvetően nem a magasabb és alacsonyabb integrációs szint (az EU és egyes nemzetállamok) eleve eltérő érdekeinek a következménye, hanem annak a következménye, hogy az EU-n belül egyes nemzetállamok - és az ezekre támaszkodó nemzetek feletti gazdasági aktorok - érdekei sokkal hangsúlyosabban érvényesülnek, mint másoké. Ezek kerülnek szembe „EU-érdekekként” a kisebb érdekérvényesítő képességú nemzetállamok (és nemzetgazdaságok) érdekeivel (lásd: Böröcz 2009, Pogátsa 2004). Mint a különböző integrációs szintek szempontjainak ilyen össze-nem-egyeztetése esetén lenni szokott-- s mint ahogy más vonatkozásban korábban mi is hangsúlyoztuk -, a résztvevők két rossz véglet felé sodródnak, s ez mindkét szinten dezintegráló hatású: az EU-szintű integráció vonzerejét csökkenti, az egyes nemzetállamokon belül pedig antagonisztikusnak tűnő ellentéteket eredményez a kétféle integrációt képviselő csoportok között. Az egyik oldalról a „magasabb szintű integráció” képviselői hajlamosak elmaradottságnak bélyegezni a nemzeti hagyományt (vagyis azokat az integrációs mechanizmusokat, amelyek a nemzetállamok és nemzetgazdaságok társadalmát összetartják); a másik oldalon a "nemzeti érdekek” képviselői meg hajlamosak lehetnek egyes, fejlődési lemaradásból következő sajátosságokat is hagyományként védelmezni. A szembenállás tápot ad annak is, hogy egy-egy, pusztán a nemzet egyes szubkultúráit képviselő csoport a „nemzettel” azonosítsa magát, más, szintén csak egy-egy szubkultúrát képviselő csoportok meg „az európaiság képviselőivé” transzformálják fel magukat.

A probléma gyökere talán abban van, hogy Európa gazdasági, társadalmi és politikai integrációja nincs összhangban. A politikai integráció az intézmények szintjén előrehaladt, de egyes (keleti, déli) nemzetállamok gazdasági függetlensége kisebb, mint a magországoké, gazdaságuk nagy részben külső tényezők által befolyásolt (és a kontinens gazdasági integrációjában kevésbé kapnak aktiv szerepet); ebből a szempontból igazából nem integrálni, hanem asszimilálni próbálják őket. Emögött pedig az van, hogy a politikai integráció nincs összhangban a társadalmi integrációval. Integrált társadalmat akarnak létrehozni, de a gazdasági egyenlőtlenségek figyelmen kívül hagyásával, amelyben a gyengébb helyzetű nemzetállamok nem lehetnek érdekeltek. Mint többször hangsúlyoztuk, a valóságos integrációnak azonban minden szereplő érdekeinek a figyelembevétele és összehangolása a feltétele. A politikai integráció is csak akkor erősödhetne, ha a keleti-déli államok is ugyanakkora beleszólást kapnának a közös európai politika kialakításába (a gazdasági vonatkozásokban is), mint a „magállamok”, s így társadalmilag is valóban integráció, és nem alávető asszimiláció következne be.

A két szint összehangolatlansága a belső politikai színtéren is megnyilvánul, például abban is, hogy az európai integráció érdekképviseletét felvállaló pártok képviselői gyakran érzéketlennek bizonyulnak az európai integráció által hátrányosan érintettek szempontjaival szemben, s ez nyilván dezintegratív hatású mind az európai integráció, mind a belső, nemzeti szintű integráció szempontjából. Mint ahogy a kontinentális integráció központi szorgalmazói is gyakran érzéketlenek azon államok polgárainak szempontjaival szemben, amelyek történelme úgy alakult, hogy a nemzeti és nemzetgazdasági függetlenség hosszan tartó hiányában az ő társadalmaikban mindmáig megvalósítandó (mert teljességében még megvalósulatlan) cél maradt a nemzetgazdaság 
általi integráció, ami az EU magországaiban már régen megtörtént. E kedvezőtlenebb történelmű országok számára nem megoldás annak hangoztatása, hogy „a jelen már nem a nemzetállamok és nemzetgazdaságok kora", amíg ugyanis ez a belső integráció nem történik meg, hátrányos-alávetett helyzetben maradnak a saját integrációjukat sikeresen végigvitt magországokkal szemben.

Másfelől ezt a nemzetgazdasági integrációt viszont nem lehet végrehajtani azon nemzeten belüli csoportok szempontjai iránti érzéketlenséggel, akiket hátrányosan érintenek egyes kormányzati intézkedések, illetve akik nem részesei egyfajta nemzeti konszenzusnak. A reformkorban, a magyar történelem azon szakaszában, amely legközelebb volt a nemzetgazdasági integráció sikeres megvalósításához éles politikai - és gazdasági ellentétek voltak az egyes csoportok között, de a születő nemzetgazdaság közös nevezője a felszabadulóban lévő jobbágyoktól az arisztokráciáig minden társadalmi csoportnak nyitott integrációs alapot kínált. A sikeres nemzeti integrációnak ma is feltétele lenne, hogy abból egyetlen társadalmi csoport se legyen kihagyható - a pártpolitikai ellenfelek sem -, mindenki megtalálhassa benne a számára megfelelő helyet.

Az európai integráció és a nemzeti integráció szempontjainak ellentétbe kerülése a 2014-es választási folyamatban az egyik legmeghatározóbb tényezővé vált. A kormánypártok sikerének egyik legfőbb komponense annak a tapasztalatnak a beépítése, hogy a jelenlegi magyar társadalom egyik érzelmekkel és indulatokkal teli alapélménye éppen e két szempont közti feszültség, s az egyik legerősebb belső integráló erő, a sokszor értetlen „magasabb szinttel” szembeni ellenállás. Az alsóbb szintek szempontjainak kellő figyelembe vétele nélkül „felülről” megkísérelt integrációra (vagy ráadásul asszimilációs nyomásra) az alsóbb szint többnyire öszszezárással reagál. Ez az „összezárás” nagy mértékben magyarázza a jelenlegi kormánypártok 2010-es és 2014es támogatottságát, (akik a nemzeti szempontok minden versenytársuknál hatékonyabbként bemutatott védelmét sikeresen helyezték kampányuk középpontjába ${ }^{48}$ ). Ez nem jelenti azt, hogy a kormánypártok ne tettek volna (akár az EU-val való kapcsolatok területén, akár a nemzeten belül egyes csoportokhoz való viszonyokban) dezintegrativ hatású lépéseket.

Mind az európai integráció, mind a nemzeti szintű integráció vonatkozásában az utóbbi évek egyik legfőbb tanulsága annak az alaptézisnek az újraigazolódása, hogy bármely felsőbb szint integrációja valóban sikeresen csak az alsóbb szintek integrációjával összhangba hozva mehet végbe.

Ha az egyes politikai aktorok döntéseitől végül ismét visszakanyarodunk a politikai rendszer egészének integrációs szerepéhez, ezzel kapcsolatban néhány további tézist szeretnénk zárásképpen megfogalmazni, illetve az ezzel kapcsolatos korábbi állításokat összefoglalni.

A választási kampány, mint a politikai rendszer múködésének eszköze elvben mozgósitó és integráló tényező: a politikai aktivitás világába bekapcsolja a választókat. (Ez alapvető cél, a kampányidőszakban mindig megjelennek olyan plakátok is, amelyek nem valamely párt választására, hanem magára a választási részvételre, a választói aktivitásra buzdítanak). Az elhúzódó kampányidőszakok - amelyek a pártok közti küzdelem kiélesedésével is összefüggenek - főleg, ha a politika a gátlástalan adok-kapokkal, a másik oldal által leleplezett törvénysértések és amorális cselekedetek sokaságával, az öncélúvá váló, a társadalom számára legfontosabb 
kérdésektől függetlenedő pártküzdelmekkel azonosítódik - kioltják az integratív hatást. Nem az aktivitást erősítik, hanem a politikától való távolságtartást, bizalmatlanságot, olykor az egész politikai elit elutasítását, vagy a társadalom egész politikai alrendszerétől való elfordulást (ami ma is jellemző például a fiatalabb generációk egyes csoportjaiban).

A pártok a kampányokban többnyire olyan értékeket jelenítenek meg, amelyek a társadalom többsége számára valóban értéket jelentenek. Sosem lehet azonban kontrollálni, hogy egy-egy hangoztatott érték mögött valójában milyen érdekek húzódnak meg. Ha a hangoztatott érték és az értéket hangoztatók gyakorlata között nagy a különbség, ez megint csak a politika iránti bizalmatlanság fokozója, és dezintegráló hatású. Persze - mint ezt korábban hangsúlyozni próbáltuk - magának egy-egy értéknek a hangoztatása mindenképpen hordoz pozitív (és integratív) mozzanatokat. Az az érték, amit hangoztatnak, objektíve is jobban elötérbe kerülhet. Lehet, hogy a határok spiritualizálásának eszménye, ezen eszmény hangoztatása, fókuszba állítása mögött „a tőke és a munkaerő szabad áramlásának"(számos negatív hatást és dezintegratív következményt is magában hordó) érdeke húzódik meg, attól még a vasfüggönyök felszámolódása, a szabad utazási lehetőség mindenképpen egy pozitív érték (s egyúttal egy integrativ tényező) erősödését jelenti. Az is igaz azonban, hogy egy értékeszmény minél nagyobb hangsúlyt kap a társadalomban, annál nagyobb lehet a feszültség az értékeszmény és a valóság között: ez egyfelől válságok forrása, másfelől viszont kikényszerítheti az értékeszmény számonkérését és a valóság valamilyen fokú közelítését ehhez az eszményhez.

A választási kampányok egyik legproblematikusabb mozzanata, hogy bennük pártok állnak a társadalom elé, de kampányaikban a pártok egyáltalán nem tesznek mindent explicitté a mögöttük álló, döntéseiket befolyásoló érdekekből. A modern pluralista pártrendszert némelyek azzal jellemzik, hogy azokat a küzdelmeket, amelyeket az antifeudális majd antikapitalista forradalmak erőszakosan, véresen és többnyire eredménytelenül (mert éppen az integráció ellenében hatóan) viszik végbe, pártok békés, parlamenti küzdelmeivé szelídítik, s ebben a formában sokkal nagyobb az esélye az érdekellentétek feloldódásának, és valódi integrációk létrejöttének. Ez a pártrendszer komoly értéke. „Békeidőben” ráadásul nem is ekkora, rendszerszintű érdekellentétek jelennek meg a pártrendszerben, hanem csak kisebb alrendszerek, szubkultúrák, érdekcsoportok ütközései. A probléma elsősorban az, hogy a pártrendszer jelenlegi múködésének alapmodellje a piaci verseny; ez viszont néha önmagában is afelé tolja a pártokat, hogy mindenáron egymás legyőzésére törekedjenek, s ez azzal is jár, hogy a küzdelem elszakadhat a valódi társadalmi érdekek képviseletétől, és a „csapatukért” mindenkivel harcba szálló futballszurkolók magatartásához közelít (az ókori Bizánc „cirkuszi pártjaihoz” hasonlóan). Sokan ezért is szeretnék a pártrendszer súlyát csökkentve a közvetlen, nem-intézményesülő érdekképviseletek szerepét megnövelni (időről-időről ezért is merül fel az olyan kétkamarás parlament gondolata, amelynek legalább egyik kamarájában időszakos, egy-egy nagy támogatottságú társadalmi „ügyre” szerveződött, - s egymással nem alapvetően versenyben álló - civil mozgalmak kapnának helyet. Ezek esetében nem arról lenne szó, hogy melyik hány helyet tud elvenni a másiktól, hanem mindenkit kötelező kompromisszumkényszerben forognának ki azok a megoldások, amelybe mindegyik résztvevő céljai „,bedolgozódhatnának”). A mai választási kampányok „élethalálharcához” képest azonban efféle - Habermas kommunikatív cselekvés-elméletével (Habermas 1989) kompatibilis -, integratív utópiák csupán az álmok távolában derengenek. 


\section{HIVATKOZÁSOK}

Ansolabehere, S. - Iyengar, S. (1995) Going Negative: How Campaign Advertising Shrinks and Polarizes the Electorate. New York: The Free Press.

Brader, T. (2005) Striking a Responsive Chord: How Political Ads Motivate and Persuade Voters by Appealing to Emotions. American Journal of Political Science, Vol. 49, Issue 2, April 2005, 338-405. http://dx.doi.org/10.1111/j.0092-5853.205.00130x.

Böröcz, J. (2009) The European Union and Global Social Change: A Critical Geopolitical Economic Analysis, London: Routledge.

Cohen, A. (1985) The Symbolic Construction of Community, Key Ideas, London-New York: Routledge. http://dx.doi. org/10.4324/9780203323373

Dingfelder, S. (2012) The Science of Political Advertising. Monitor Staff, April 2012, Vol 43, No. 4 Print version: page 46. http://dx.doi. org/10.1037/e540732012-023.

Douglas, M. (1975) Implicit Meanings. Essays in Anthropology. London: Routledge and Kegan Paul, London \{magyarul: Rejtett jelentések, Budapest: Osiris, 2003\}.

Firth, R. (1973) Symbols - Public and Private. Ithaca: Cornell Univ. Press.

Geertz, C. (1973) The Interpretation of Cultures, New York: Basic Books.

Geertz, C. (1994) Az értelmezés hatalma. Budapest: Osiris.

Gerbner, G. (2000) A média rejtett üzenete, Budapest: Osiris-MTA-ELTE.

Green, D. P. - Gerber, A. S. (2004) Get Out the Vote: A Guide for Candidates and Campaigns, Washington D.C.: Brookings Institution Press.

Habermas, J. (1989) The Theory of Communicative Action II. (Lifeword and System: a Critique of Funcionalist Reason). Boston: Beacon Press. Magyarul: A kommunikatív cselekvés elmélete. I-II. Budapest: ELTE Filozófiaoktatók Továbbképző és Információs Központja - ELTE Szociológiai Intézet és Továbbképző Központ, (Filozófiai Figyelő és Szociológiai Figyelő kiadványa).

Jakobson, R. - Halle, M. (1956) Fundamentals of Language. 's Gravenhage: Mouton. http://dx.doi.org/10.1515/9783110894264.

Kapitány Á. - Kapitány G. (1990) Értékválasztás, 1990. Budapest: Múvelődéskutató Intézet.

Kapitány Á. - Kapitány G. (1994) Értékválasztás, 1994. Budapest: Friedrich Naumann Stiftung - Societas.

Kapitány, Á. - Kapitány, G. (1996) Changing World-Views in Hungary 1945-1980. Journal of Popular Culture, (USA), 1996, 33-43. http://dx.doi.org/10.1111/j00223840.1995.2902_33x.

Kapitány Á. - Kapitány G. (1998/a) Értékválasztás, 1998, Budapest: Új Mandátum.

Kapitány Á. - Kapitány G. (1998/b) Systemwechsel und Symbolwechsel in Ungarn, 1989-1996. In Pribersky, A. - Unfried, B. (eds.) Symbole und Rituale des Politischen: Ost- und Westeuropa im Vergleich. Serie: "Historisch-Antropologische Studien", Frankfurt/Main: Peter Lang Verlag, 159-174.

Kapitány Á. - Kapitány G. (2002) Magyarság-szimbólumok, Budapest: Európai Folklór Intézet.

Kapitány Á. - Kapitány G. (2003) Értékválasztás, 2002, Budapest: Új Mandátum.

Kapitány Á. - Kapitány G. (2006) Symbols and communication of values in the accession to the EU (Hungary) Semiotica, (La sémiotique politique/Political semiotics, Special issue), Mouton de Gruyter, Vol. 159. 2006/1-4,111-141. http://dx.doi. org/10.1515/sem.2006.024.

Kapitány Á. - Kapitány G. (2007) Értékválasztás, 2006, In Sándor P. - Vass L. - Tolnai Á. (szerk.) Magyarország Politikai Évkönyve (kormányzat, közpolitika, közélet). Budapest: Demokrácia Kutatások Magyar Központja Alapítvány, II/1148-1187).

Kapitány Á. - Kapitány G. (2008) A szimbólum arcai, Jel-Kép, 2008/2, 63-73

Kapitány Á. - Kapitány G. (2009) Visual symbols of political system-change in Hungary In Tarasti, Eero (szerk): Communication: Understanding/Misunderstanding. (Proceedings of the $9^{\text {th }}$ Congress of the IASS/AIS - Helsinki-Imatra: 11-17 June, 2007.) Acta Semiotica Fennica XXXIV. Imatra-Helsinki: International Semiotics Institute-Semiotic Society of Finland, II/695-706.

Kapitány Á. - Kapitány G. (2010) Pártok és szubkultúrák a választási kampány tükrében, Értékválasztás 2010. In: Antalóczy T - Füstös L- Hankiss E (szerk.): Mire jó a kultúra? Jelentés a magyar kultúra állapotáról, No. 2. Budapest: Magna produkció.

Kapitány Á. - Kapitány G. (2012) Symbolic Elements of Everyday Culture. Studies in Sociology/Szociológiai Tanulmányok 2012/2. Budapest: MTA TK SZI/Institute of Sociology, Centre for Social Sciences, Hungarian Academy of Sciences, Budapest, 2012, e-book: http://www.socio.mta.hu/dynamic/st_soc_3_kapitany.pdf.

Kapitány Á. - Kapitány G. (2014) A mindennapi élet jelrendszereiröl. Szocio-szemiotikai tanulmányok, Budapest: Loisir.

Kapitány Á. - Kapitány G. (2015) The semiotic dimensions of vertical social (self) classification, Semiotica, 2015. Vol. 205, 243-260. http://dx.doi.org/10.1515/sem.2015.0012. 
Király J. (2010) A film szimbolikája (A filmkultúra filozófiája és a filmalkotás szemiotikai esztétikája), Kaposvár-Budapest: Kaposvári Egyetem Művészeti Kar, Mozgókultúra Tanszék - Magyar Televízió Zrt.

Kiss B. (2013) Érzelmek és politikatudomány. Politikatudományi Szemle XXII. 2013/3, 7-29.

Leach, E. (1976) Culture and Communication: the Logic by which Symbols are Connected, Cambridge: Cambridge Univ. Press, http:// dx.doi.org/10.1017/cbo9780511607684.

Niven, D. (2004) A Field Experiment on the Effects of Negative Campaign Mail on Voter Turnout in a Municipal Election, Columbus, Ohio: Ohio State University Press.

Osgood, Ch. E. - Suci, G. J. - Tannenbaum, P. H. (1957) The Measurement of Meaning, Urbana and Chicago: Univ. of Illinois Press.

Randviir, A. - Cobley, P. (2009) Introduction: What is Sociosemiotics? Semiotica 173: 1/4, 1-39. http://dx.doi.org/10.1515/ sem.2009.001.

Pogátsa Z. (2004) Europe Now: Hungary's Preparations for the EU's Structural and Cohesion Funds, Szombathely: Savaria University Press.

Turner, V. (1974) Dramas, Fields and Metaphors. Symbolic Action in Human Society. Ithaca: Cornell Univ. Press.

Turner, V. (1987) The Forest of Symbols, Ithaca: Cornell Univ. Press. 